$$
\begin{aligned}
& \text { UCRL } 9193 \\
& \text { CALIVERSITY OF }
\end{aligned}
$$

Ernest O. Saurence Radiation

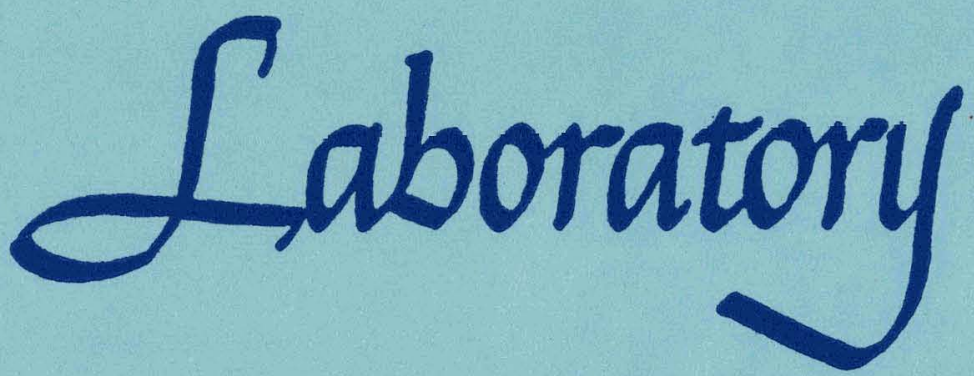

\title{
LONGITUDINAL DISPERSION IN BEDS OF FINELY DIVIDED SOLIDS
}

BERKELEY, CALIFORNIA 


\section{DISCLAIMER}

This report was prepared as an account of work sponsored by an agency of the United States Government. Neither the United States Government nor any agency Thereof, nor any of their employees, makes any warranty, express or implied, or assumes any legal liability or responsibility for the accuracy, completeness, or usefulness of any information, apparatus, product, or process disclosed, or represents that its use would not infringe privately owned rights. Reference herein to any specific commercial product, process, or service by trade name, trademark, manufacturer, or otherwise does not necessarily constitute or imply its endorsement, recommendation, or favoring by the United States Government or any agency thereof. The views and opinions of authors expressed herein do not necessarily state or reflect those of the United States Government or any agency thereof. 


\section{DISCLAIMER}

Portions of this document may be illegible in electronic image products. Images are produced from the best available original document. 
UCR L-9193

UC-4 Chemistry General

TID -4500 (15th Ed.)

\section{UNIVERSIT Y OF CALIFORNIA \\ Lawrence Radiation Laboratory \\ Berkeley, California \\ Contract No. W-7405-eng -48}

LONGIT UDINAL DISPERSION IN BEDS OF FINELY DIVIDED SOLIDS

Jerry Max Robinson

(M. S. Thesis)

June 1960 
Printed in USA. Price \$1.25. Available from the office of Technical Services U. S. Department of Commerce Washington 25, D.C. 


\section{Contents}

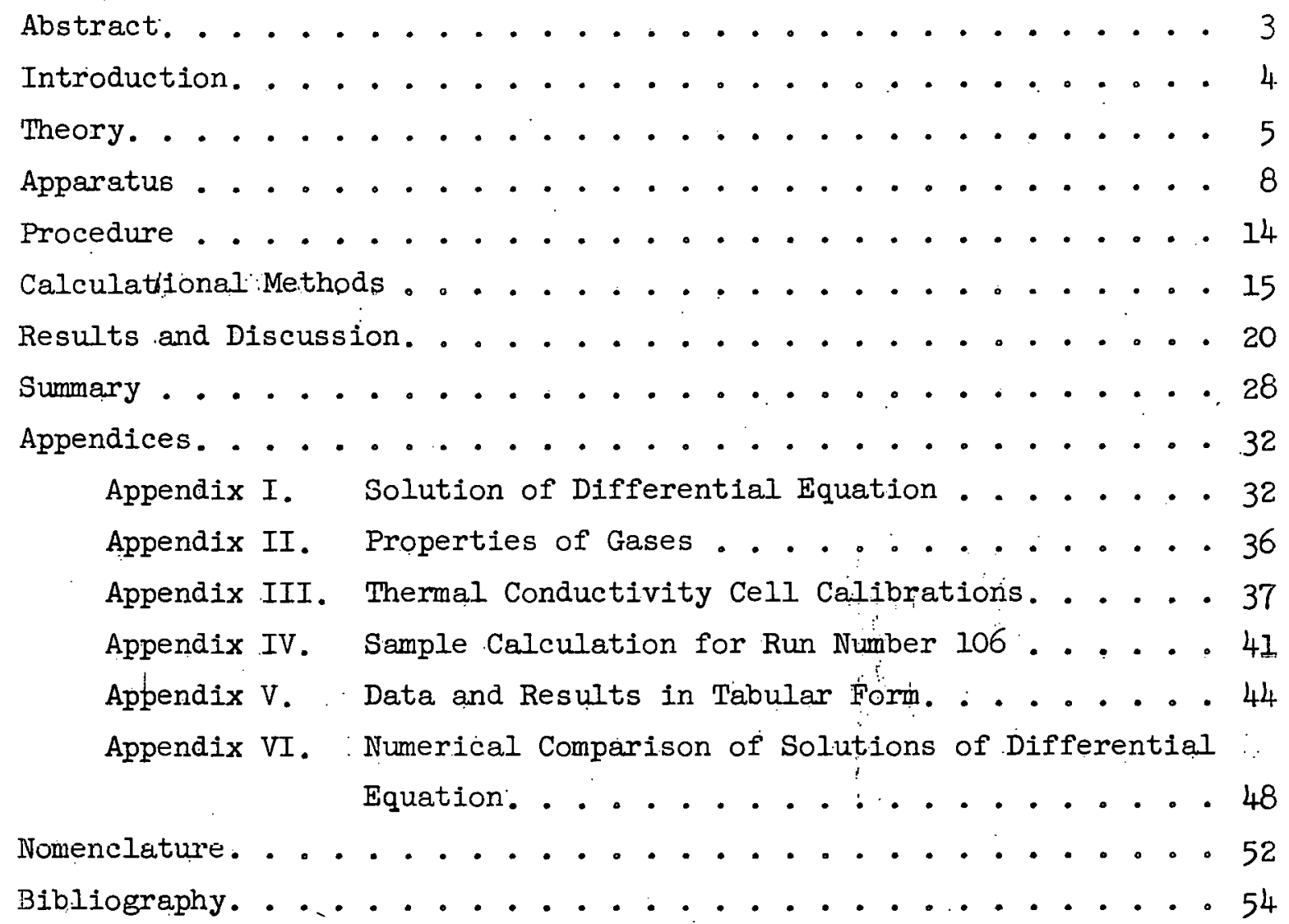


LONGITUDINAL DISPERSION IN BEDS OF FINELY DIVIDED SOLIDS

Jerry Max Robinson

Lawrence Radiation Laboratory and Lepartment of Chemical Engineering University of California, Berkeley, California

June 1.960

ABSTFACT

Experimental determinations of the longitudinal dispersion coefficient and the Peclet number were made for three binary gas systems. The experimental technique involved measuring the dispersion of a step function input to a column packed with glass beads.

The diffusional model was employed to obtain the differential equation describing longitudinal dispersion in a packed column. This equation was solved with suitable boundary conditions, and the solution was used in the analysis of the experimental dispersion data.

The experimental results show a variation in the Peclet number from 0.1 to 0.6 , and in the eddy dispersion coefficient from 0.03 to $1.0 \mathrm{~cm}^{2} / \mathrm{sec}$ for the Reynolds number range from 0.03 to 1.0 . 


$$
-4-
$$

LONGITUDINAL DISPERSION IN BEDS OF FINELY DIVIDED SOLIDS

Jerry Max Robinson

Lawrence Radiation Laboratory and Department of Chemical Engineering University of California, Berkeley, California

$$
\text { June } 1960
$$

\section{INTIRODUCTION}

The analysis of problems concerning fluid flow through packed columns often involves assumption that the molecules of the fluid pass through the column with no longitudinal dispersion taking place. However, because of the random motion of the molecules and macroscopic mixing from turbulence, such dispersion does occur. The effect of this is to reduce the heat-and mass-transfer driving potentials to values below those expected from the "plug flow" assumption. In the design of packed extraction columns, gas-liquid partition chromatography columns, ionexchange columns, etc., this dispersion results in a reduction in column efficiency that cannot be calculated without further knowledge of longitudinal dispersion phenomena.

Gaseous systems at high Reynolds numbers have been investigated by McHenry and Wilhelm, 14 who found that for Reynolds numbers between 10 and 400 the Peclet number is approximately constant at 1.88. This value agrees closely with the estimated upper limit of 2 for the Peclet number. 1,4,14,15 A few gas system runs were made by Carberry and Bretton ${ }^{4}$ in the low-Reynolds-number range, but the data were scattered and seem inconclusive.

Liquids flowing through various packing materials have been studied by using pulse, step, and sinusoidal input functions by the following investigators:

Ebach and White ${ }^{7}$ used pulse inputs at low flow rates and sinusoidal inputs at high flow rates to measure Peclet numbers over a Reynolds number range of 0.01 to 200 .

A pulse function input was used by Carberry and Bretton, who examined the Reynolds number range from 1 to 400. The Peclet numbers determined in their investigation show effects of bed length, particle size, and particle shape. 
Strang and Geankoplis ${ }^{17}$ gathered data in the Reynolds number range from 5 to 20 by the use of sinusoidal input functions. Although the data are scattered and the Peclet number is found to depend on bed length, the results agree fairly well both with Carberry and Bretton and with Ebach and White.

The investigators mentioned above based their mathematical analysis on the diffusional model. Both E.J. Cairns ${ }^{5}$ and Jacques, Cotter, and Vermeulen ${ }^{10}$ employed a statistical model originally developed by H. A. Einstein: 8 .They also used step-function inputs of salt oolution, and analysis bascd on clcctrical conductivity.

The object of this investigation was to relate longitudinal dispersion coefficients, for gaseous systems at low Reynolds numbers, to the system variables.

\section{THEORY}

In the development of the theory of longitudinal dispersion, there have been three mathematical models proposed. The most widely used of these is the diffusional model, which is described below. The other two are the cell-mixing model and the random-walk model.

The cell-mixing model is based on an analogy between a packed bed and a series of mixing vessels. The packed bed is considered to be composed of interconnected mixing cells. Although the mixing-cell model has been analyzed, ${ }^{I}$ the results are difficult to use because they contain parameters that can not be readily evaluated, i.e., cell-mixing efficiency, length of a perfect mixing cell, etc.

The random-walk model is based on the analysis by $H$. A. Einstein of the motion of pebbles in a flowing stream. It is assumed that a nolecule of a fluid flowing through a packed bed undergoes a series of "motion phases", in which it moves with the fluid, and "rest phases", in which it is stagnant. The statistical analysis of this motion yields. results that can readily be used in the reduction of experimental data. 5,10 
The diffusional model, which was used in this study, is based on the assumption that transport of a fluid through a packed column takes place by three mechanisms: convective flow, molecular diffusion, and macroscopic mixing due to turbulence. This last is assumed to occur in a manner analogous to molecular diffusion, and an equation similar to Fick's Law of Diffusion is used to define an eddy dispersion coefficient, E. E is defined by

$$
N_{e}=-E \frac{\partial C}{\partial x}
$$

where $\mathrm{N}_{e}=$ mass flux due to eddy dispersion,

$\mathrm{E}=$ eddy dispersion coefficient,

$\mathrm{C}=$ concentration of solute gas,

$\mathbf{x}=$ distance from the column entrance.

It is also assumed that the interstitial velocity $V$. is a constant independent of position in the bed and equals $v_{0} / \epsilon$, where $v_{0}$ is superficial velocity based on the cross sectional area of the empty column and $\epsilon$ is the vold fraction of the column packing. Concentration, then, is a function only of distance from the column entrance and time, e.g., $c=f(x, t)$.

Based on the above assumptions, a material balance over a short section of the column yields the differential equation

$$
D \frac{\partial^{2} c}{\partial x^{2}}-v \frac{\partial c}{\partial x}=\frac{\partial c}{\partial t}
$$

where

$$
\begin{aligned}
& D=\text { longitudinal dispersion coefficient, } D_{m}+E, \\
& t=\text { time. }
\end{aligned}
$$

In order to solve this differential equation it is necessary to have three boundary conditions, two in space and one in time. In this analysis we are interested in the introduction of either a pulse function or a step function of a gas into a packed column in which a different gas is flowing. Obviously, then, the time boundary condition is $C(x, 0)=0$ for all $x$, and one of the space boundary conditions is 
determined by the charging function at $x=0$. For a step function input of material whose solute concentration is $\mathrm{C}_{0}$, the charging function is

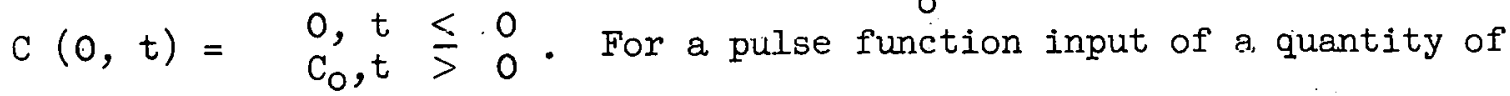
solute $\mathrm{q}$, the charging function is

$$
A \in \int_{0}^{\infty}\left(V C-D \frac{\partial C}{\partial x}\right) d t=q
$$

where $A$ is the cross-sectional area of the empty column.

The final boundary condition is not so obvious, however. If the finlte culumin of lcngth L may he rnnsidered equivalent to a length $L$ of an infinite column, then

$$
\lim _{x \rightarrow \infty} C(x, t)=0
$$

is a valid boundary condition. Otherwise, the boundary condition

$$
\frac{\partial C(L, t)}{\partial x}=0
$$

as derived by Danckwerts, 6 may be used. In order for the Danickwerts boundary condition to be valid, the ratio of the longitudinal dispersion coefficients immediately outside the columin and lumediately inoide the column must approach zero. At high fluid velocities the eddy-dispersion coefficient inside the column is much greater than that outside, and the Danckwerts assumption is reasonable. At low fluid velocities, however, the longitudinal dispersion coefficients, both inside and outside the column, approach the molecular diffusion coefficient, and their ratio approaches unity. In this case the solution resulting from the Danckwerts boundary cundition is not valid. Since this investigation is concerned with low fluid velocities, the infinite column assumption is used:

The solutions of equation (1) derived from the inf'inite-column assumption, for step function and pulse function inputs, respectively, are 


$$
\frac{c}{C_{0}}=\frac{1}{2}\left[e^{s} \operatorname{erfc}\left(\frac{1+s \eta}{2 \sqrt{\eta}}\right)+\operatorname{erfc}\left(\frac{1-s \eta}{2 \sqrt{\eta}}\right)\right]
$$

and

$$
C=\frac{q}{A L \epsilon}\left[\frac{1}{\sqrt{\pi \eta}} e^{-\frac{(1-s \eta)^{2}}{4 \eta}}-\frac{s}{2} e^{s} \operatorname{erfc}\left(\frac{1+s \eta}{2 \sqrt{\eta}}\right)\right]
$$

where $s=\frac{V L}{D}$ and $\eta=\frac{D t}{L^{2}}$. For details of solutions see Appendix I.

Alternative solutions are obtained from consideration of the diffusional model with different boundary conditions, 9 the cell-mixing model, 1 and the random-walk model. 5 In all cases, however, the solutions converge toward a Gaussian distribution as the length of the column is increased. For short columns the solutions are appreciably different, but experimentäl difficulties arising due to end effects make it difficult to determine which solution fits the physical situation most precisely. To compare the solutions of equation 1, obtained by various investigators, the IBM-650 computer was programmed to calculate concentration versus time curves from each solution. This comparison is shown in Appendix VI. This. investigation was confined to long columns in which there is no appreciable difference in the various solutions.

The solution of Eq. (1), then, approaches a Gaussian distribution. ${ }^{13}$ Therefore the peaks of the pulse function experiments, at $\mathrm{C}=\mathrm{C}_{\max }$, and the midpoints of the step function experiments, at $\frac{C}{C_{0}}=0.5$, occur at $\mathrm{s} \eta=1$.

\section{APPARATUंS}

The experimental equipment cons1sted of a gas supply, pressuremeasurement and -regulation devices, an input function system (pulse or step), a packed column, a thermal conductivity (TC) cell, a recording potentiometer, and a flow-rate-measuring device. A schematic diagram of the experimental apparatus is shown in Fig. 1.

Gas was taken from pressurized gas cylinders equipped with pressure-reducing valves for rough output-pressure adjustment. The gases used were helium, air, nitrogen, aild ethylene. Their specifications are listed in Appendix II. 


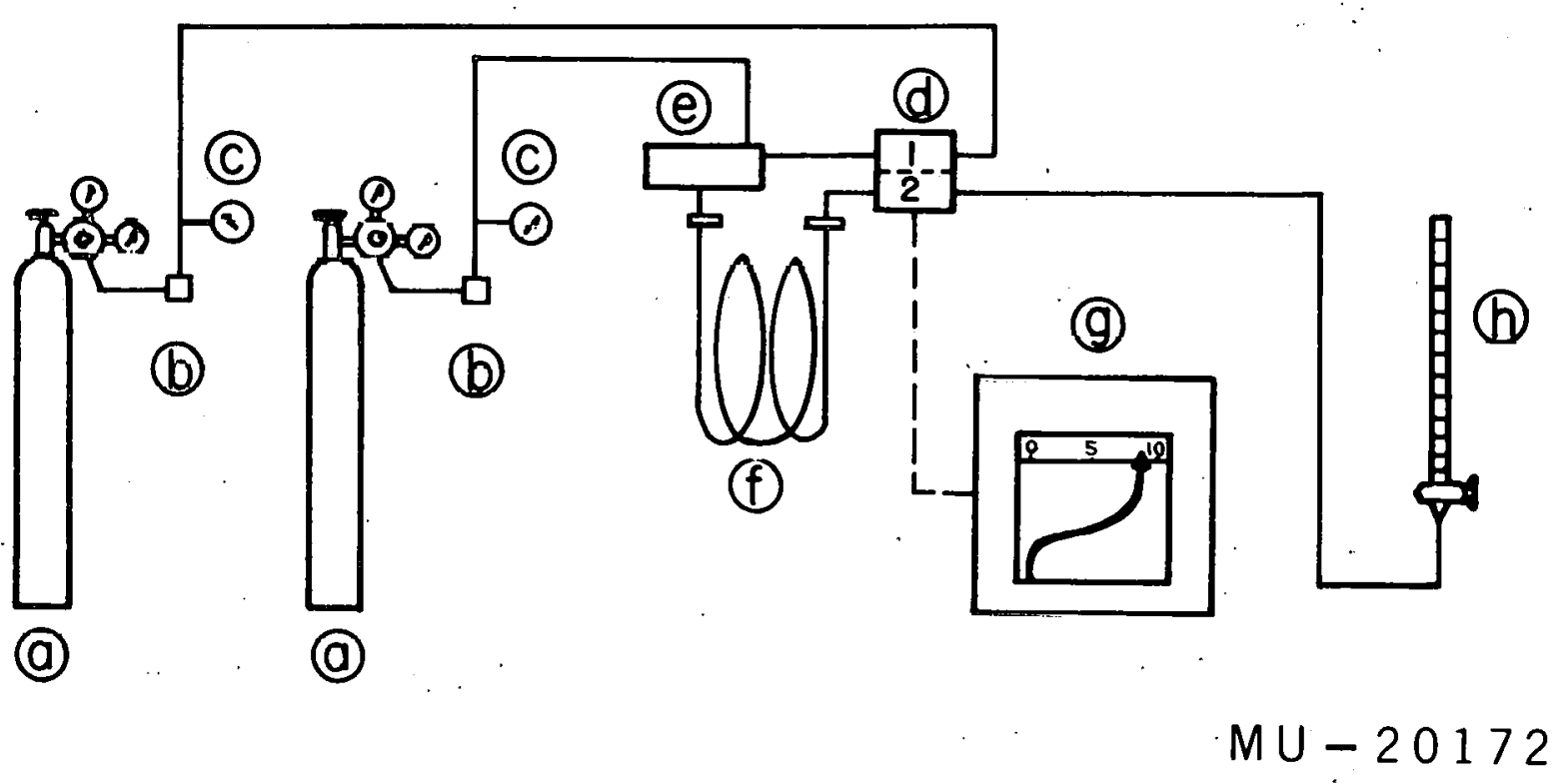

Fie. 1. Schematic diagram of experimental equipment.

(a) compressed-gas cylinder

(b) pressure control

(c) pressure gauge

(d) thermal conductivity cell

(1) reference side

(2.) sample side

(e) input-function device

(f) column packed with glass beads

(g) recording potentiometer

(h) soap-film meter (burette). 
Fine pressure regulation was accomplished with a Manostat Corporation No. 6 manostat and a National Welding Equipment Company No. 708-G pressure regulator. The column inlet and outlet pressure were measured with an Ascroft No. 1082A gauge and a U. S. Gauge No. 10763-1, respectively, each with a range of 0 to 100 psig.

The input function system for the step function was simply a 1/8-inch pipe tee with quick opening valves on two ends of the tee; the other end led to the column entrance. This system is shown in Fig. 2 . The pulse function device was essentually a system of interconnected sliding chambers. It is shown in Figs. 3 and 4 to facilitate visualizing its operation. In Position 1 the gas flows directly from the reference side of the TC cell into the column. In this position the sample tube was filled with the component to be charged. The piston was then pushed to Position 2. This diverted the gas so that it flowed through the sample tube and charged the sample to the column. Construction was of copper, and the interchamber seals were rubber 0 rings. The sample tube was 1/4-inch copper tubing of suitable length to produce the sample volume desired.

The packed columns were 3/8-inch copper refrigerator tubing with a wall thickness of 0.032 inch. They were packed with 20-40 mesh (U.S. Standard screens) glass pavement-marking beads obtained from Minnesota Mining and Mfg. Company. Average particle diameter was 0.0246 inch. The columns were packed by inserting a small, porous glass wool plug in one end, suspending a column vertically, and slowly pouring the beads into the column. During the packing operation, the columns were vibrated by tapping to insure random packing with no trapped air pockets, and the other end was plugged with glass wool. This packing had a void fraction of 0.359. All columns had the same inside diameter ( 0.311 inch), packing diameter (0.0246 inch), and packing void fraction (0.359). The only parameter that varied was column length.

Analysis of the gas stream was accomplished with a Gow Mac model 9285 thermal conductivity cell. Adjustments were provided to vary the cell current from 0 to 150 milliamperes. Current was drawn from a standard 6-volt battery. 


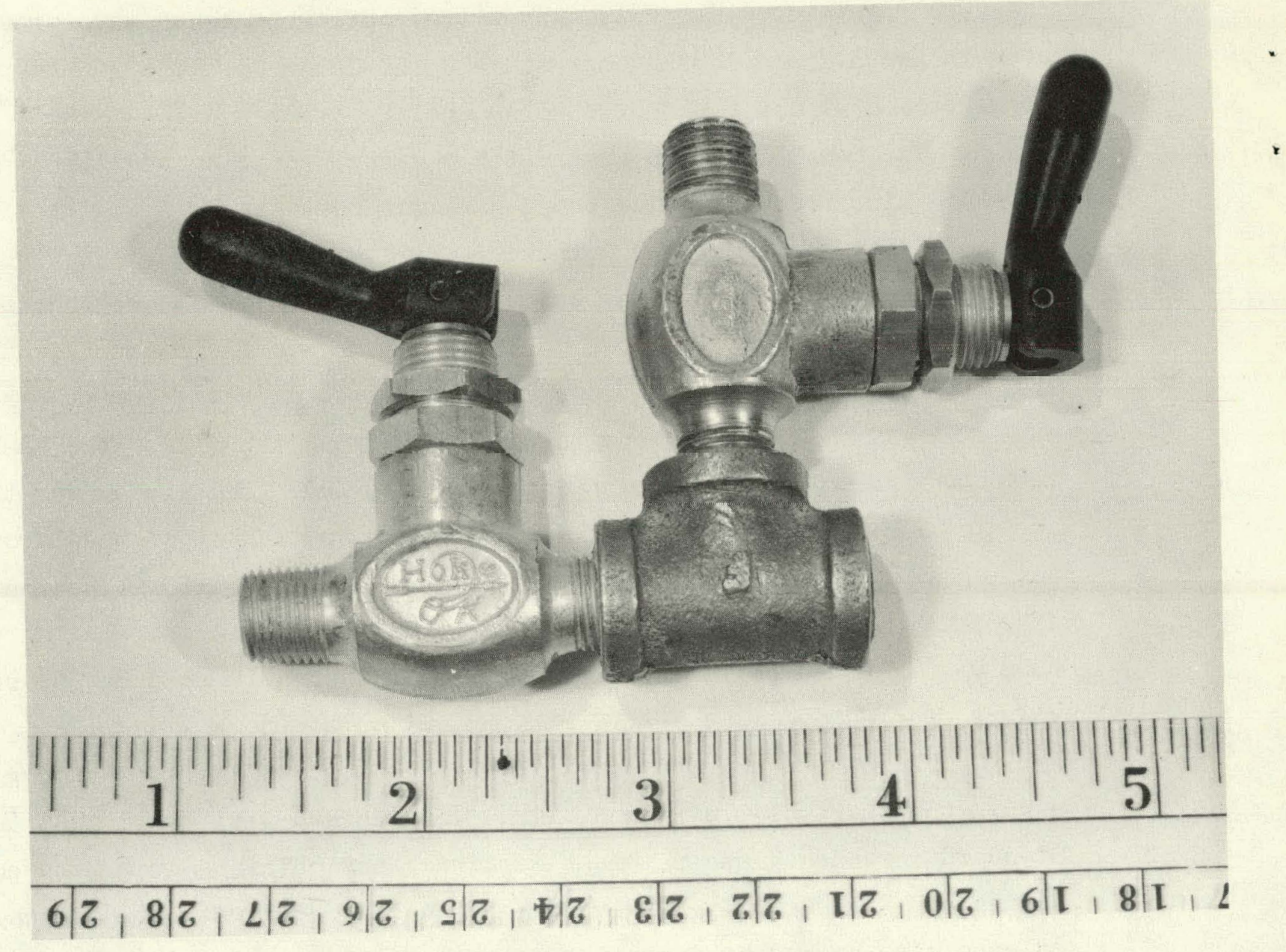

$\mathrm{ZN}-2455$

Fig. 2. Step function input system. 


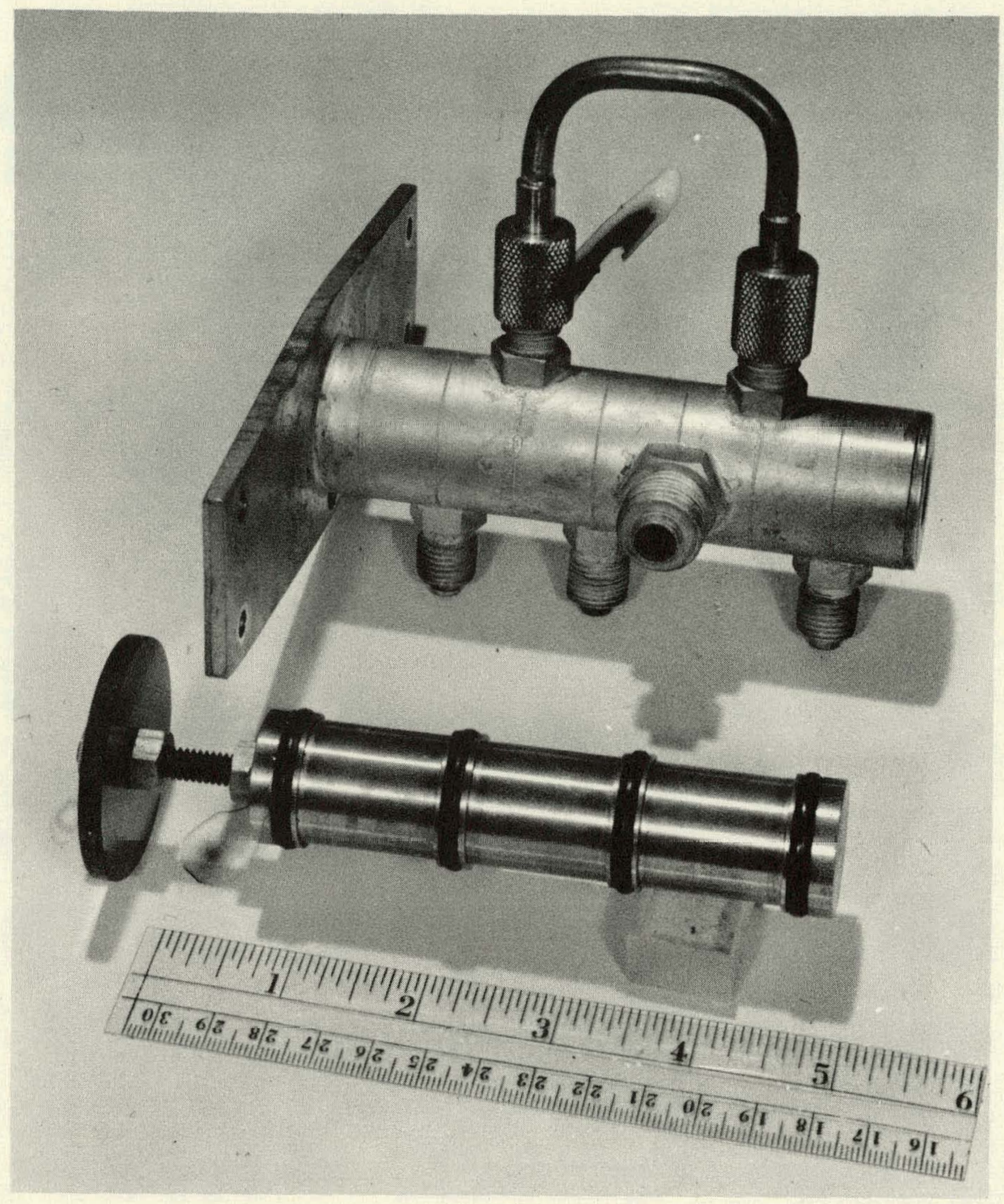

$\mathrm{ZN}-2454$

Fig. 3. Pulse-function device showing outer cylinder and charging piston. 
Position 1
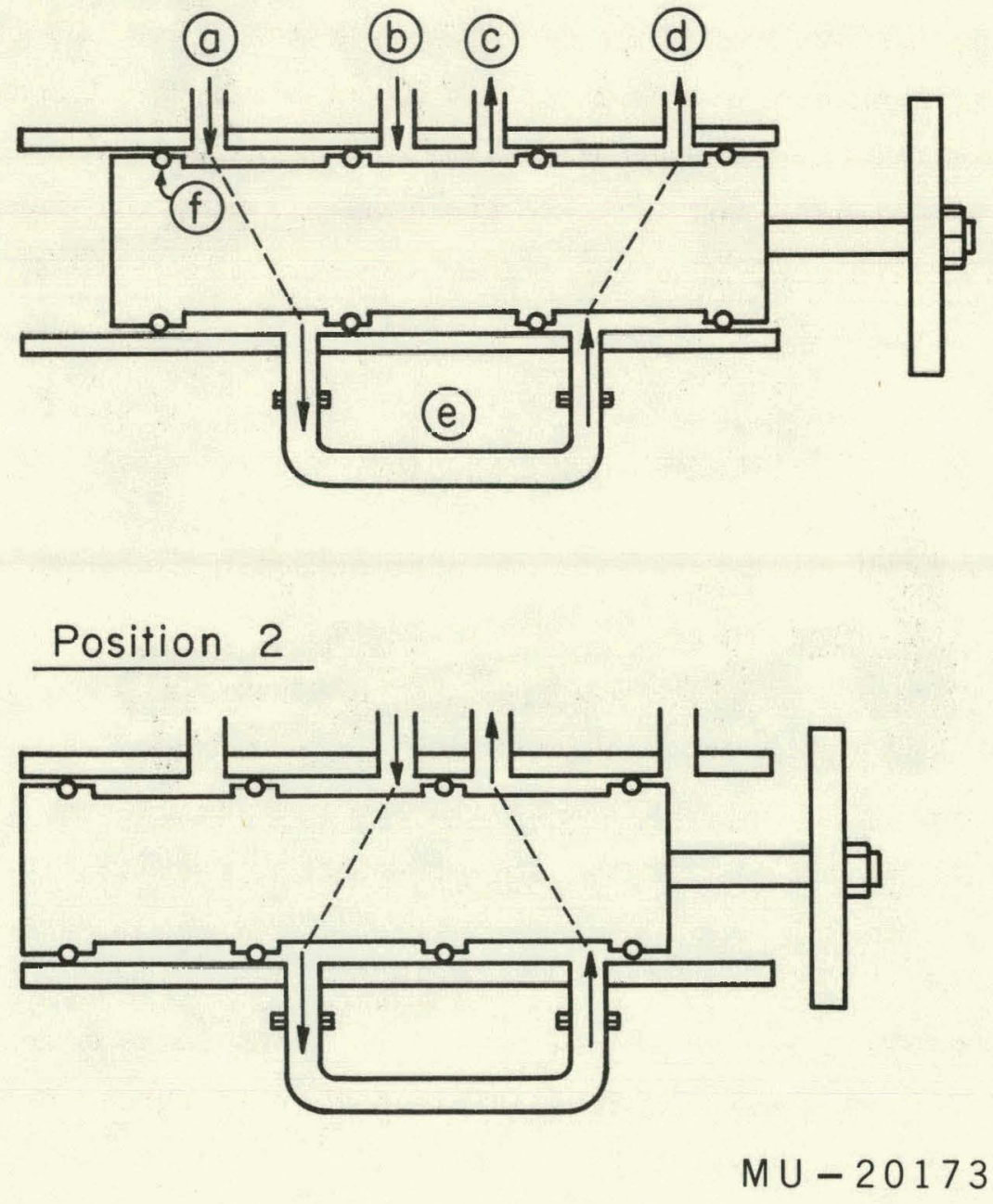

Fig. 4. Schematic diagram of pulse-function device.
(a) sample inlet
(b) reference gas from TC cell
(c) column entrance
(d) sample exhaust
(e) sample tube
(f) rubber 0-ring seals. 
The signal from the TC cell, resulting from a change in concentration (thermal conductivity), was recorded on a Leeds and Northrup. Speedomax recording potentiometer. The range of the recorder was 0 to. 10 millivolts, but attenuation of the TC cell signal was provided to make full-scale recorder readings represent from 10 to 10,000 millivolts.

To measure the very. Iow gas flow. rates ( 5 to $100 \mathrm{ml} / \mathrm{min}$ ) used in this work, a burette. was used as a soap-film meter. A soap-film meter is extremely accurate and gives virtually no back pressure. ${ }^{12}$. The flow rate was controlled with an Ohio Chemical and Surgical Equipment needle valve No. 304-5208-800 having a long tapered valve stem for precise control.

\section{PROCEDURE}

The procedure followed in making experimental determinations for a step function input was as follows:

(a) The valves on the gas cylinders were opened, and the pressure adjusted..with the pressure regulators and manostat to give the desired operating pressure.

(b) The snap-open valves were positioned so that only the reference gas was flowing, and the gas-flow rate through the column was adjusted with the needle valve.

(c) The TC Cell was turned on and the cell current adjusted to either 100 or 120 milliamperes. This number is rather arbitrary and affects only the sensitivity of the cell. ${ }^{12}$

(d) The recorder was turned on and balanced to give a zero voltage reading.

(e) The following parameters were recorded: date, gas system used, column pressure, column length, room temperature, and cell current.

(f). The positions of the quick-opening valves were reversed to produce a step function, and a start mark was made on the recorder chart. If this changed the recorder zero, balancing was repeated.

(g) The gas-flow rate was measured with the soap-film meter by introducing a drop of soap solution into the burette and timing the rise 
of the resultant bubble through a given volume. The volume of gas displaced and the displacement time were recorded. This step was repeated frequently throughout the run and the average value was used in the calculations.

(11) A permancit rccord ohowing the response of the TS cell as a function of time was produced by the recording potentiometer.

$\therefore$ For a pulse function input, "... Step $f$ was changed to:

$(\mathrm{r}-1)$ With the charging piston in Position 1 , the sample tube was filled with the gas to be used for the pulse. The piston was pushed to Position 2 to produce the pulse, and a start mark was made on the recorder chart.

\section{CALCULATIONAL METHOD}

Data reduction was accomplished by making use of the fact that for large $s$ values the peaks of the pulse-function experiments, at $\mathrm{C}=\mathrm{C}_{\max }$, and the midpoint of the step-function experiments, at $\frac{\mathrm{C}}{\mathrm{C}_{\mathrm{O}}}=0.5$, are at $\mathrm{s} \eta=1$. Considering this, Eqs. (2) and (3), respectively, were simplified and solved for $s$ to get

$$
s=4 \pi\left(\frac{\mathrm{dc} / \mathrm{C}_{0}}{\mathrm{~d} t / t_{.5}}\right)_{s \eta=1}^{2}=4 \pi\left(\frac{t .5}{\mathrm{y}_{0}} \frac{\mathrm{dy}}{\mathrm{dt}}\right)_{\mathrm{c} \eta=1}^{2}
$$

and

$$
s=4 \pi\left(\frac{A I \in C_{\max }}{q}\right)^{2}
$$

A typical recorder-response curve is shown in Fig. 5 for a stepfunction input. Since the raw data are in voltage versus time, and Eq. (4) is in terms of mole fraction and time, we must make use of a calibration curve for voltage versus mole fraction, (see Appendix III).

The time at which $s \eta=1, \dot{t}_{\text {mid }}$, is easily determined, since it corresponds to $\frac{y}{y_{0}}=0.5$. Knowing $r_{0}$ and $r$ versus $y$, then, we can. determine $y_{0}$ and obtain $r$ at $\frac{y}{y_{0}}=0.5$. When $r$ versus $y$ is a straight line, this is at $\frac{r}{r_{0}}=0.5$. 
$.-16-$

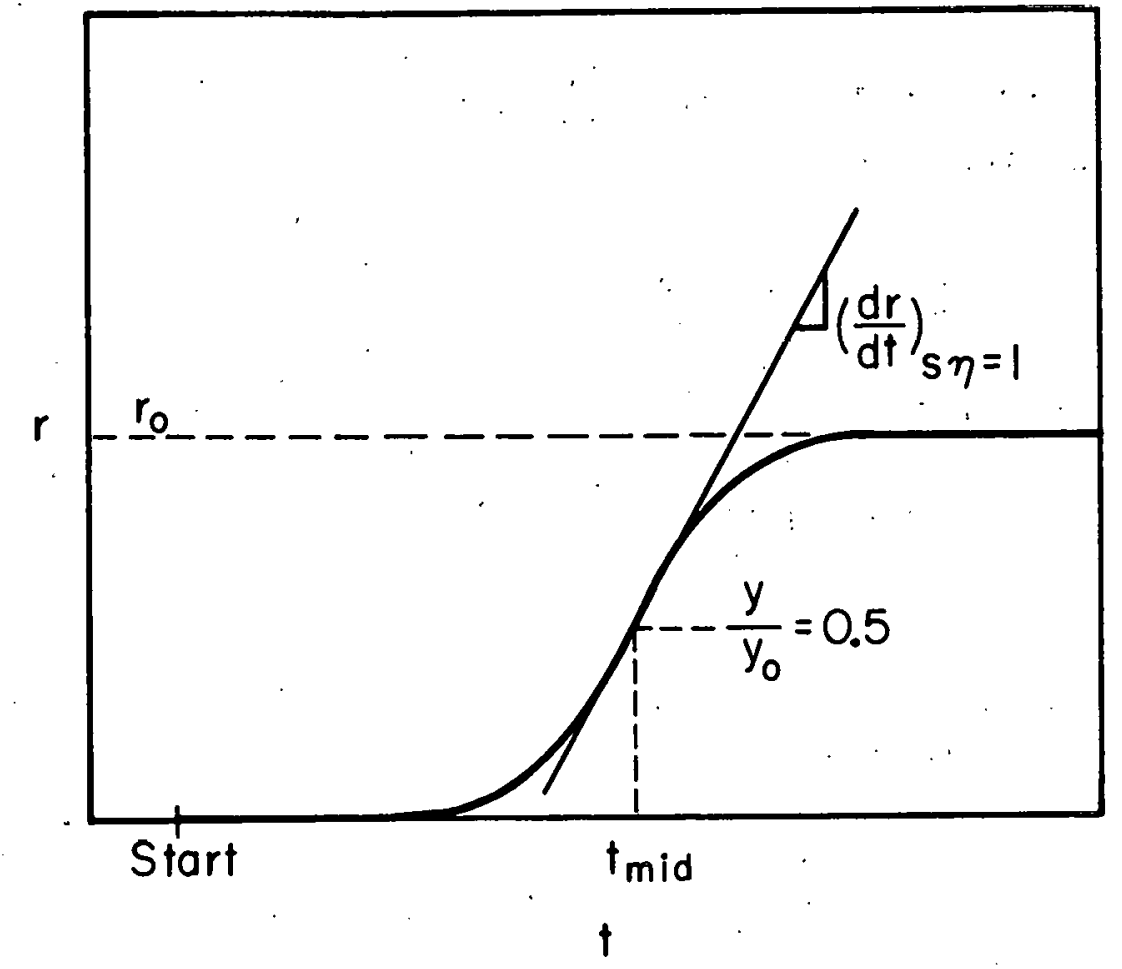

$M U-20174$ 
The time required for the breakthrough curve to flow from the column exit to the TC cell is $t_{f}$, and

$$
t_{.5}=t_{\operatorname{mid}}-t_{f}
$$

Since $\frac{d r}{d t}$ is known and $\frac{d y}{d t}$ is desired for use in Eq. (4), we make use of the relation

$$
\frac{d y}{d t}=\frac{d r}{d t} \frac{d y}{d r}
$$

Equation (4) becomes

$$
s=4 \pi\left(\begin{array}{lll}
\frac{t}{y_{0}} \cdot 5 & \frac{d r}{d t} & \frac{d y}{d r^{x}}
\end{array}\right)_{5 \eta=1}^{2},
$$

and $\frac{d y}{d r}$ can be obtained from y versus $r$. When $y$ versus $r$ is a straight line over the region of interest, we have

$$
\frac{y}{y_{0}}=\frac{r}{r_{0}}
$$

and Eq. (8) reduces to

$$
s=4 \pi\left(\begin{array}{ll}
\frac{t}{r_{0}} & \frac{d r}{d t}
\end{array}\right)_{\frac{r}{r_{0}}=0.5}^{2}
$$

A typical recorder response curve is shown in Fig. 6 for a pulse function input. Equation (5) is used to calculate s.

The appropriate $r$-versus-y curve is used to evaluate $y_{\max }$ from $r_{\max }$, and $C_{\max }$ is obtained from

$$
\mathrm{C}_{\max }=\frac{\mathrm{P} \mathrm{y}_{\max }}{\mathrm{RT}} \text {. }
$$

The value of $q$ can be determined by two methods. The first method is to calculate the volume of the sample system from the physical dimensions and use 
$-18-$

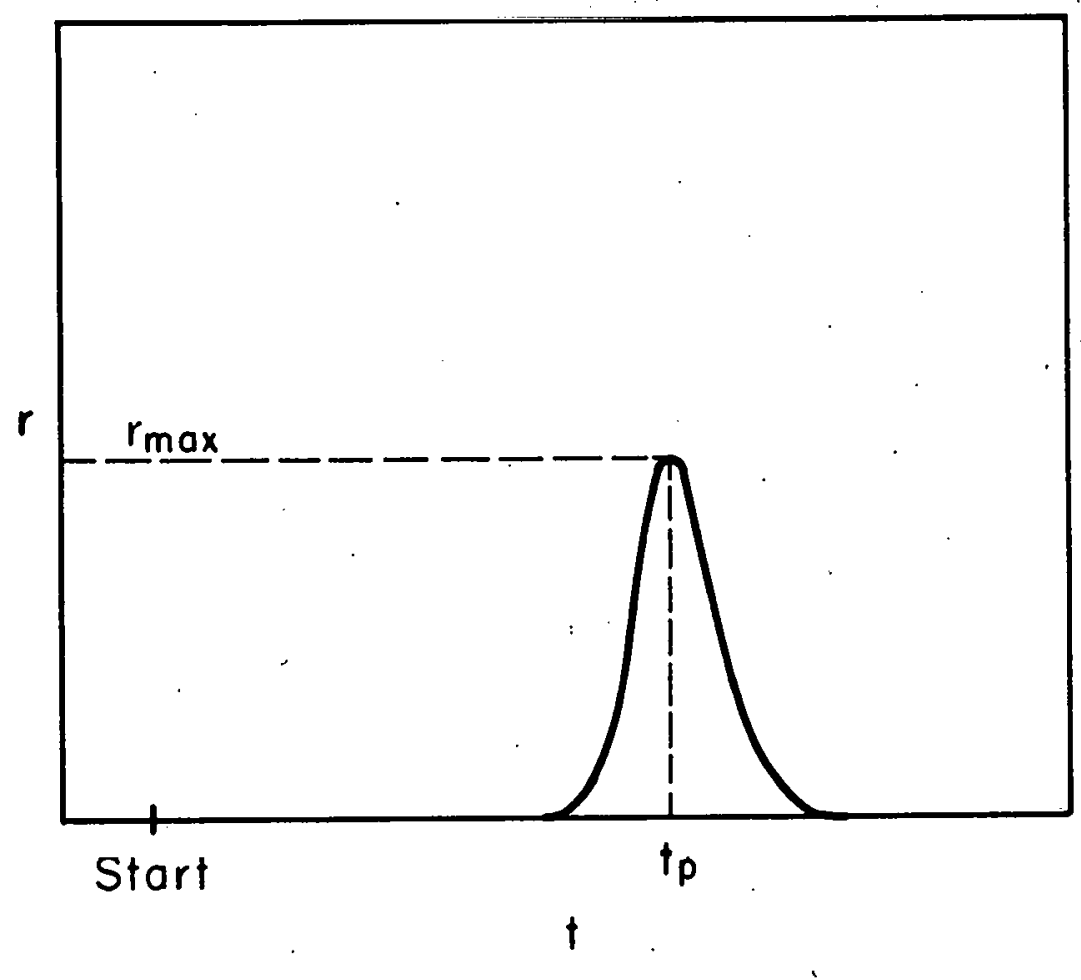

$M U-20175$

F1g. 6. A typicar recorder-response curve for a pulse-function input. 


$$
\mathrm{q}=\frac{\mathrm{P} V}{\mathrm{RT}}
$$

The second method is based on the fact that the area under the response curve is determined by the amount of somplc injected,

$$
q=A V \epsilon \int_{b}^{\infty} c d t .
$$

The $q$ value used in the calculations $\left(7.30 \times 10^{-7} \mathrm{lb}\right.$ mole) was obtained from the dimensions of the sample system, and was found to agree satisfactorily with an approximate value ( $7.6 \times 10^{-7} \mathrm{lb}$ mole) obtained by averaging the results of numerical integration of recorder-responee curves. Simpson's method was ueed for this integration.

The void fraction of the column packing was determined by packing a graduated cylinder with the column packing and measuring the amount of water required to fill the void volume. The vold fraction obtained in this manner was 0.359 . The void volume could also be determined from the time required for the pulse or step function to pass through the column. The result obtained by this method fluctuated somewhat, but the average value of 0.362 compares very well to the other method.

In the determination of the gas flow rate with the soap-film meter, the presence of water vapor in the gas was neglected, since the amount present was unknown. The maximum error possible, which would occur if the gas were saturated, is less than $3 \%$.

After determination of the $s$ value, as described above, the longitudinal dispersion coefficient and the Peclet number can readily be calculated, since $D=\frac{V L}{s}$ and $P e=\frac{{ }_{p}}{L}$. The eddy diffusivity is obtained from $D$ and $D_{m}$, since

$$
\mathrm{E}=\mathrm{D}-\mathrm{D}_{\mathrm{m}}
$$

When values of the molecular diffusion coefficients for the binary gases were not available in the literature, they were estimated by using the Hirschfelder, Curtiss, and Bird method with the correction proposed by Wilke and Lee. ${ }^{16}$ The estimated values for $D_{m}$ at $10 \mathrm{psig}$ and $297^{\circ} \mathrm{K}$ were 


$$
\begin{array}{ll}
\text { for helium-air, } & D_{\mathrm{m}}=0.425 \mathrm{~cm}^{2} / \mathrm{sec}, \\
\text { for air-ethylene, } & D_{\mathrm{m}}=0.100 \mathrm{~cm}^{2} / \mathrm{sec} .
\end{array}
$$

Reid and Sherwood ${ }^{16}$ gave $D_{m}=0.0970 \mathrm{~cm}^{2} / \mathrm{sec}$ for nitrogen-ethyllene at the same conditions.

The densities of gas mixtures were calculated by using mole fraction; weighted averages. Viscosities of gas mixtures were calculated by the method of Bromley and wilke. 3

A sample calculation is included in Appendix IV.

\section{RESULTS AND DISCUSSION}

The experimentally determined curve of $\mathrm{C}$ versus $\mathrm{t}$ for run number 106, which used a step-function input, and the corresponding curve calculated from Eq. (2) are shown in Fig. 7. Since the two curves agree quite closely, the diffusional model employed is believed to be an adequate. representation of the physical situation, and the equations developed from it are believed valid.

As a test of experimental technique; an equivalent series of runs was made using step- and pulse-function inputs. The results obtained by using these two different experimental techniques (pulse-: and step-: function input), shown in Fig. 8 as Pe versus Re, are almost the same; therefore, they are independent of the experimental technique employed. With the exception of this test, all data reported herein were taken by using a step function input.

It was found that the longitudinal diffusivity was a function of column length for columns shorter than 20 feet. Figure 9 shows this effect for the air-ethylene system. This was probably due to end effects . at the column entrance and exit, which caused turbulent mixing. For long columns ( 20 to 40 feet) this mixing.was negligible in comparison with the dispersion taking place inside the column. Only results obtained by using the 20 - and 40-foot columns have been used herein for final interpretation of the data. 


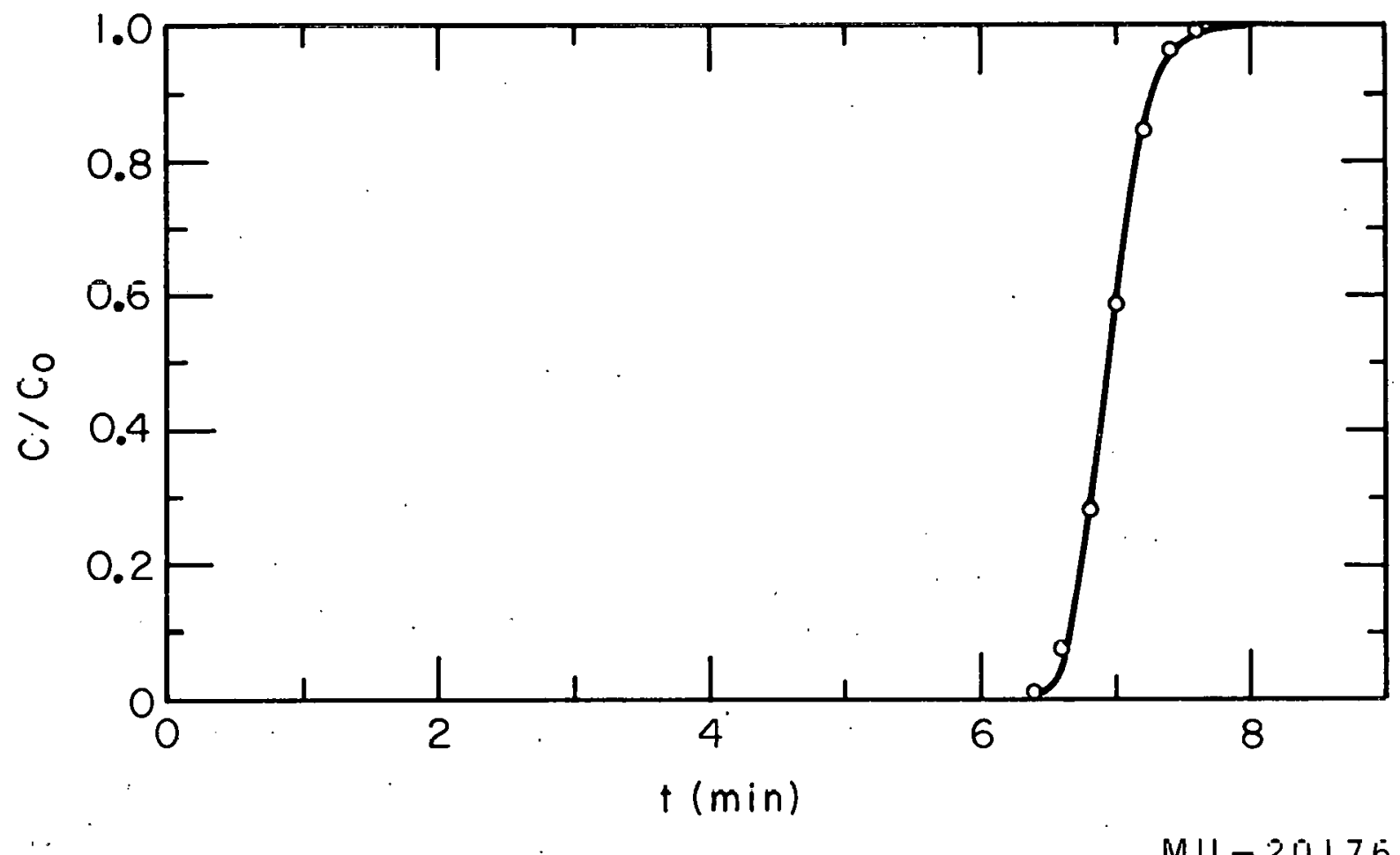

Fig. 7. Comparison of experimental and calculated C-vs-t curves for run No. 106.

- points calculated from $\mathrm{Eq}$. (2). 


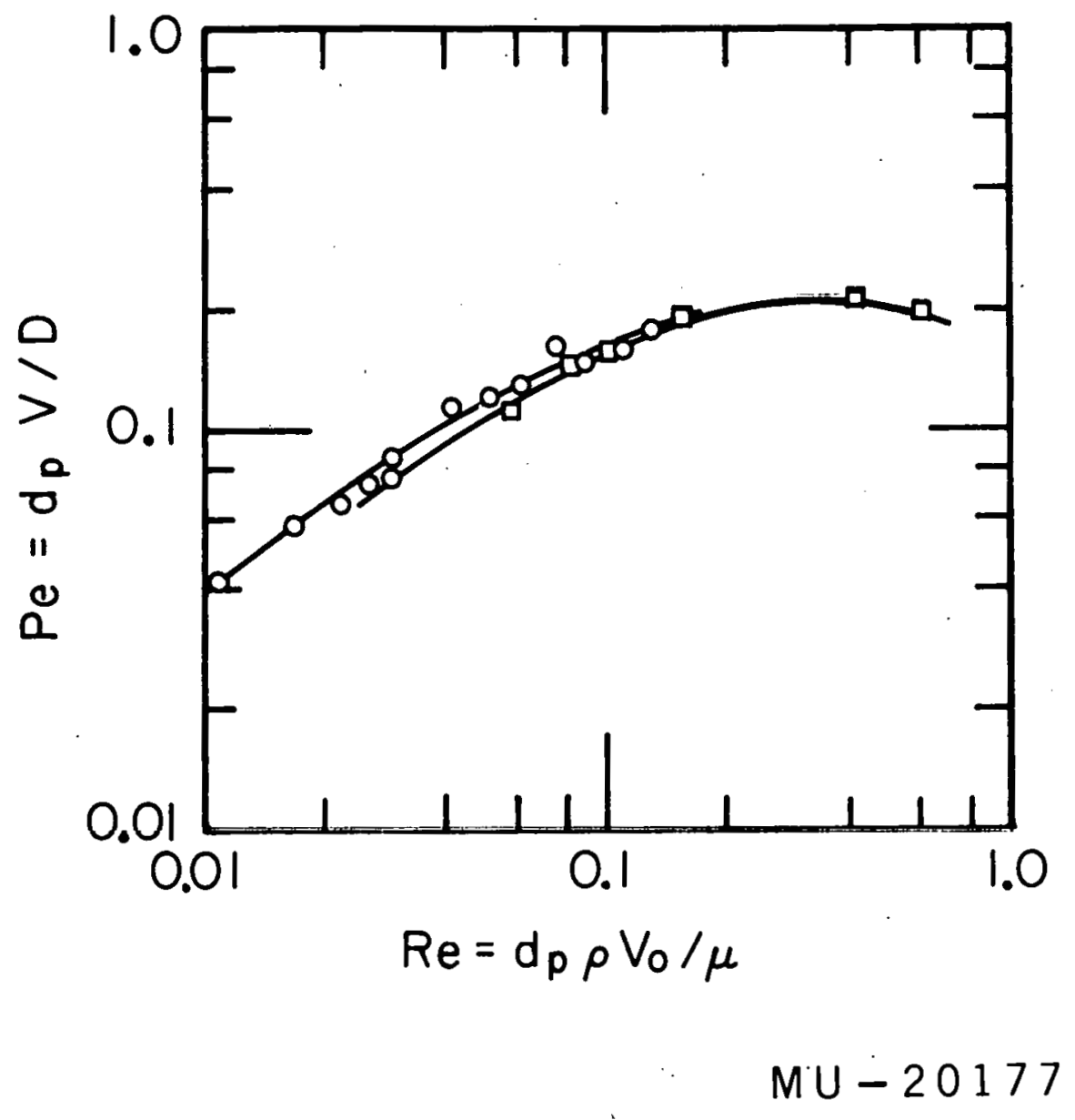

F1g. 8. Comparison of pulse- and step-function inputs. Key: O Step-function input $\square$ pulse-function input hellum-alr system 10-ft column. 


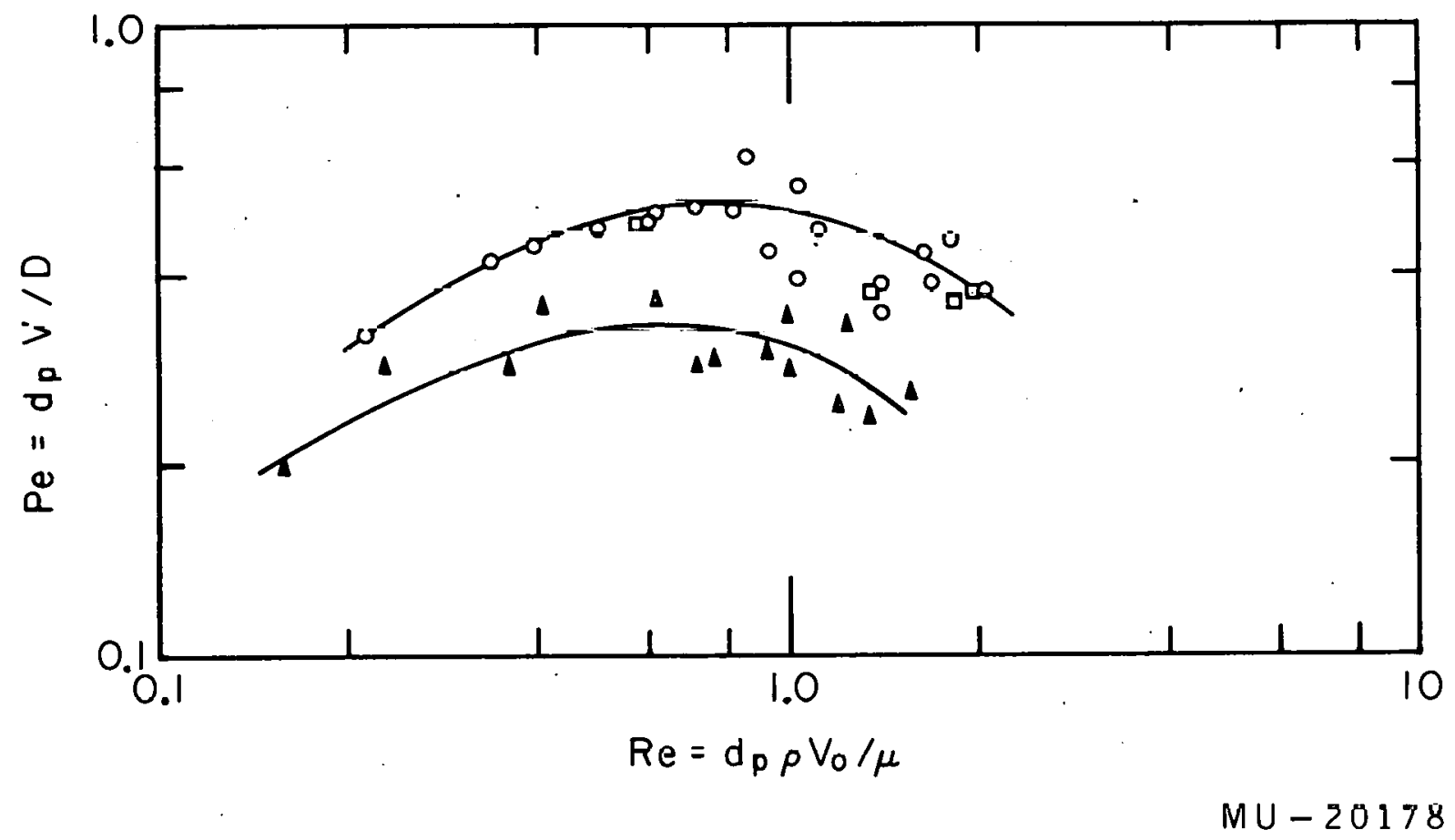

Fig. 9. Effect of column length on apparent Peclet number. Key: 10-foot column

O 20-foot column

$\square$ 40-foot column air-ethylene system. 
In order to minimize the possibility of mixing by natural convection, the systems used in this study were chosen so that the density difference between components was small. For the air-ethylene and .... nitrogen-ethylene systems the density differences $\left(4.4 .5 \times 10^{-3} 1 \mathrm{~b} / \mathrm{ft}^{3}\right.$ and $0 \mathrm{lb} / \mathrm{ft}^{3}$, respectively) were very small and the pure gases were used. For the helium-air system, however, the density difference between the pure components was $0.1075 \mathrm{lb} / \mathrm{ft}^{3}$. Consequently, a mixture of air in helium was made for which $\mathrm{y}_{\text {air }}=0.146$, and this mixture was used as one component of the system. The resulting density difference was 0.0157 $1 \mathrm{~b} / \mathrm{ft}^{3}$.

In the past, longitudinal dispersion data generally have been presented by plotting dimensionless groups characteristic of the dispersion process and the turbulence induced by the flow of the fluid. The group chosen to characterize turbulence has been the Reynolds number,

$$
\operatorname{Re}=\frac{d_{p} \rho V_{0}}{\mu}
$$

and the Group chosen to characterize dispersion has been the Peclet number,

$$
P e=\frac{d_{p} \cdot V}{D} .
$$

The results of this work are shown in this manner in Fig. 10. Figure 11 shows the results of this work together with those of other recent investigators.

The gas data of Carberry and Bretton ${ }^{4}$ were obtained by injecting a pulse of air into a helium stream. The column used was a "gas chromatographic column several meters in length." The properties of the packing used in the column were not presented. To get their data in terms of the coordinates of Fig. Il, it was necessary to assume a void fraction for their column packing. The packing usually used in chromatographic columns j.s crushed firebrick, and a representative value of the porosity of this packing is $0.6 .^{9}$ Incidentally, if the data from this investigation are plotted in the same manner as those presented by Carberry and Bretton, 


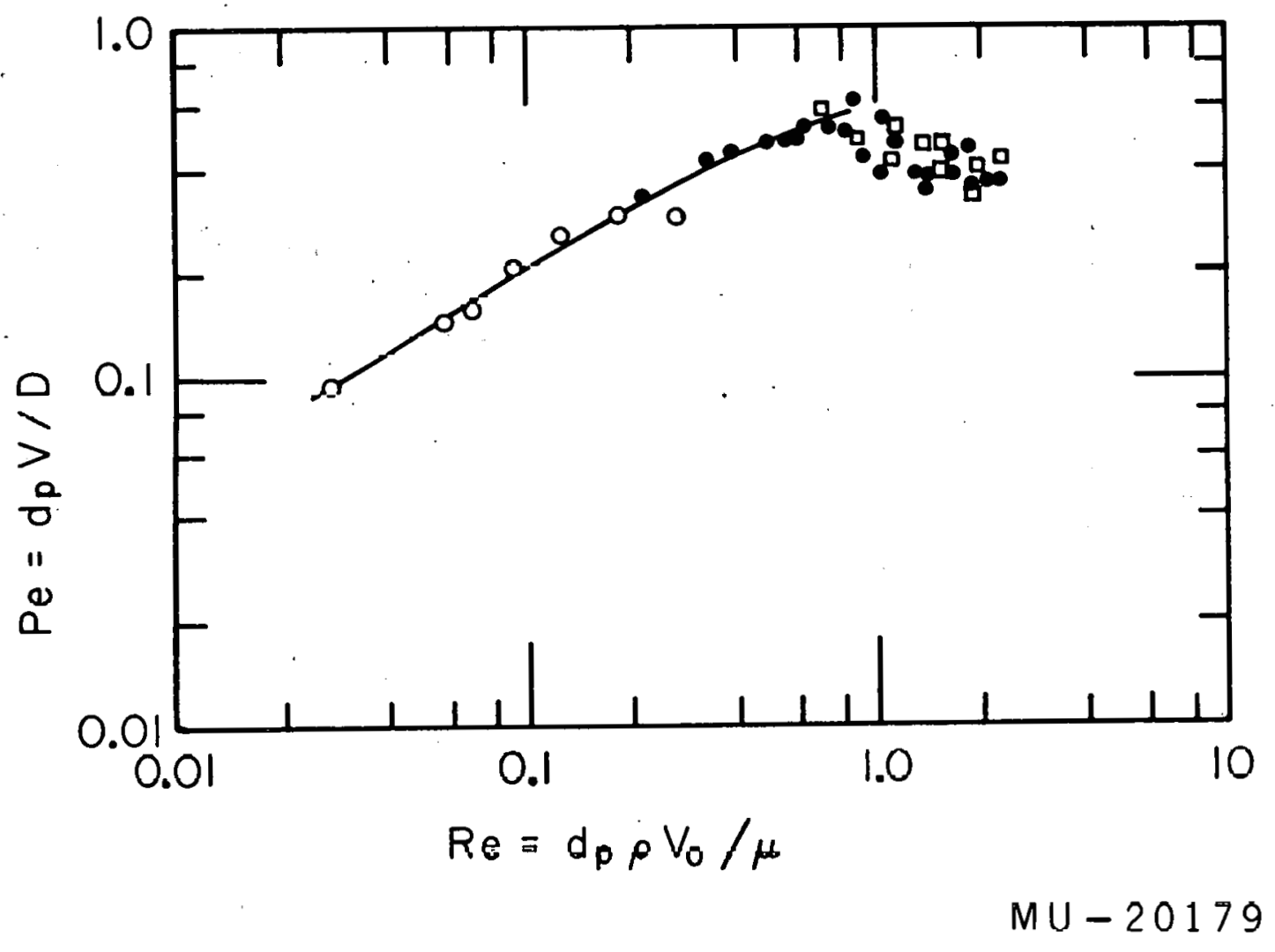

Fig. 10. Peclet number as a function of Reynolds number. Key: O helium-air system

- air-ethylene system

$\square$ nitrogen-ethylene system. 


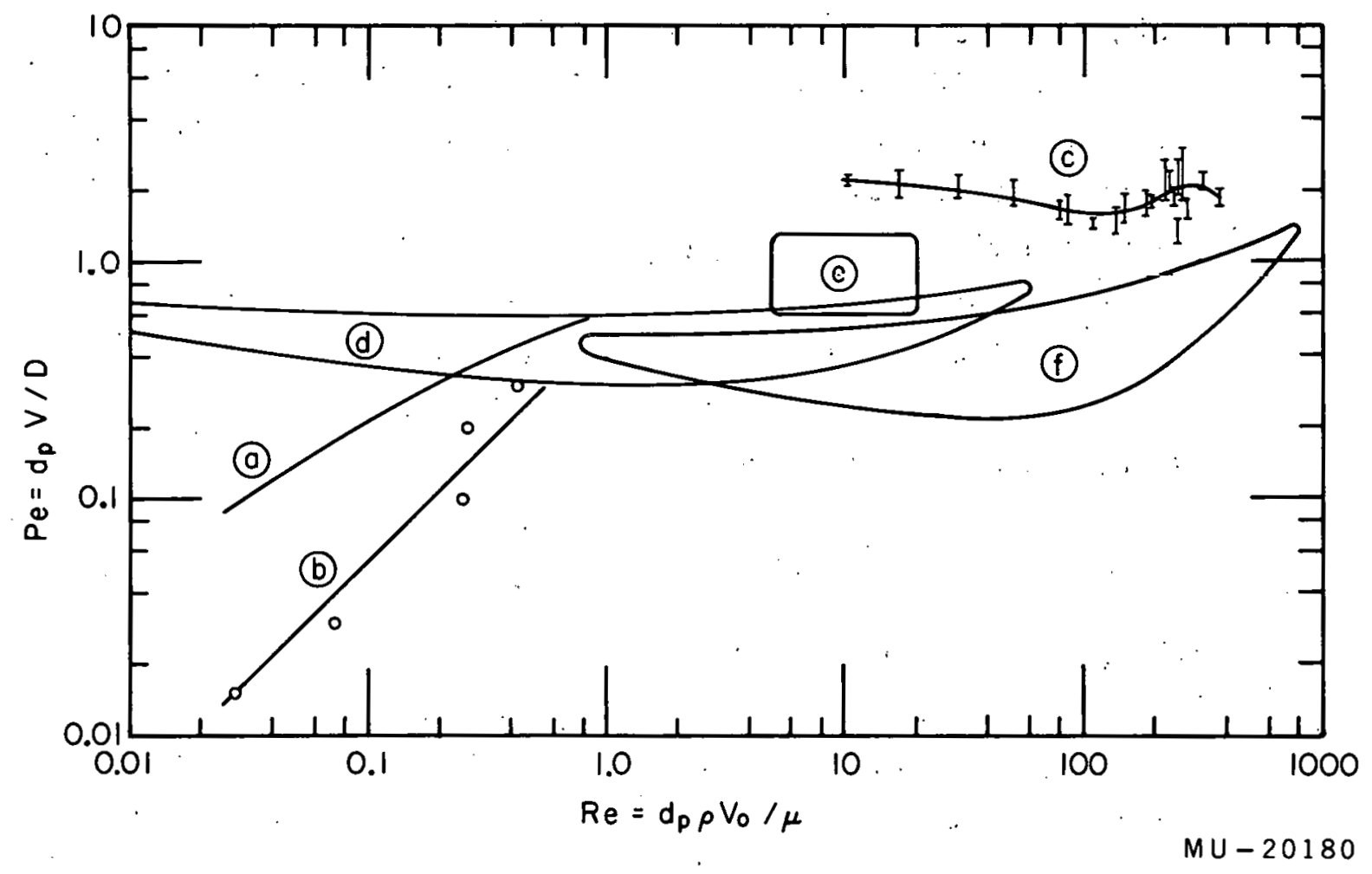

Fig. 11. Comparison with other data as Peclet number versus Reynolds number.
(a) This work
(b) Carberry and Bretton
(gas)
(c) McHenry and Wilhelm
(gas)
(d) Ebach and White
(gas)
(e) Strang and Geankoplis
(liquid)
(f) Carberry and Bretton
(liquid)
(liquid). 
the relative positions of the two curves are the same. The lower Peclet numbers obtained by Carberry and Bretton might be expected owing to the dispersijve effect of diffusion within the porous packing, ${ }^{17}$ and possibly free convection effects due to the large density difference when the air pulse was injected into the helium stream.

Intuitively, it would seem that the Peclet number should increase with increasing Reynolds number; however, the Peclet numbers in Fig. 10 reach a maximum and then decrease. This is believed to be due to the experimental difficulty in producing a perfect pulse- or step-function input. In order for the input funetion to he a gend approximation of $a$ step function, its slope must be large in comparison with that of the concentration profile at the column exit. For a step function input, then, it is necessary that

$$
(\mathrm{dc} / \mathrm{dt})_{t=0}>>(\mathrm{dc} / \mathrm{dt})_{t=t_{.5}}
$$

The decrease of Pe with increase of Re occurred when this condition was not rulfilled and the input function ceased to be a good approximation of a step or pulse function. In the absence of the above limitation it is believed that the data of this investigation would extrapolate into those of McHenry and Wilhelm ${ }^{14}$ with satisfactory agreement. The data of McHenry and Wilhelm and of Ebach and Whitc ${ }^{7}$ (in the high Re range) were obtained by using a sinusoidal input function that is not subject to the above limitation. Their method, however, leads to "analytical difficulty" at low Reynolds numbers. 7

Ebach and White have studied the effect of viscosity on longitudinal mixing for liquid systems and found no variation with viscosity over the range of 1 to 26 centipoises. The Reynolds number, then, may not be anjapt choice of variables to characterize the variation of the Peclet number. The cell-mixing model suggests a proportionality between the eddy dispersion coefficient and the product of particle diameter and interstitial velocity. In an attempt to generalize, Cairns? has proposed that the particle diameter be replaced by a hydraulic radius, $4 \mathrm{~m}$, where

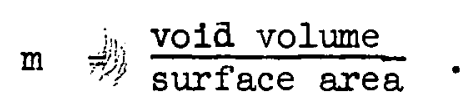


For spherical particles in a cylindrical tube we have

$$
4 m=\frac{D_{c} \epsilon}{3 / 2 D_{c} / d p(1-\epsilon)+1}
$$

The data would then be represented by a plot of $4 \mathrm{mV}$ versus the eddy dispersion coefficient or a modified Peclet number, $\frac{4 \mathrm{mV}}{\mathrm{F}}$. Representative data are shown on this type of plot in Figs. 12 and 13. The gas data of Carberry and Bretton are not shown, since the parameters necessary to convert to these coordinates are not available.

Jacques, Cotter, and Vermeulen ${ }^{10}$ have proposed alternative definitions of the Peclet and Reynolds numbers in an effort to account for particle size and shape effects which they found in their investigation. These definitions are

$$
P e^{\prime}=P e \epsilon=\frac{d_{p} V_{0}}{E}
$$

and

$$
\operatorname{Re}^{0}=\frac{\operatorname{Re}}{I-\epsilon}=\frac{{ }_{p} \rho V_{0}}{\mu(I-\epsilon)}
$$

This type of correlation is shown in Fig. 14.

Experimental data and results are presented in tabular form in Appendix V.

\section{SUMMARY}

Experimental determinations of the Peclet number and longitudinal dispersion coefficient were made for three gas systems. The analysis of the experimental data was based on the solution of the differential equation resulting from the use of the diffusion model.

The experimental technique employed a thermal conductivity cell to measure the degree of dispersion of a step function due to passage through a column packed with glass beads.

The results of this investigation show a variation in the Peclet number from 0.1 to 0.6 , and in the eddy dispersion coefficient from 0.03 to $1.0 \mathrm{~cm}^{2} / \mathrm{sec}$ for the Reynolds number range from 0.03 to 1.0 . 


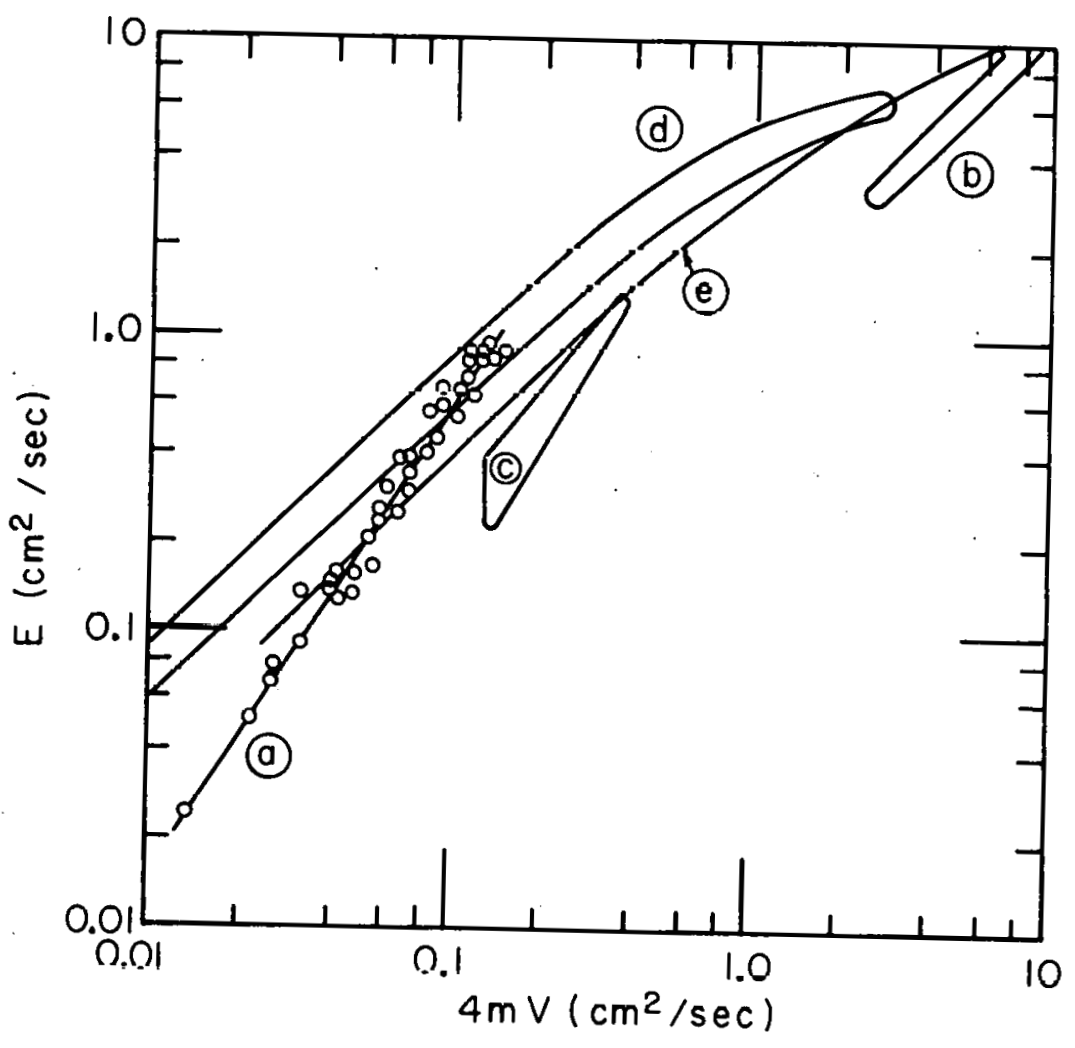

$M U-20181$

Fig. 12. Comparison with other data given as E vs $4 \mathrm{mV}$ (after Cairns).
(a) This work
(b) McHenry and WilheIm
(c) Strang and Geankoplis
(gas)
(gas)
(d) Carberry and Bretton, and Ebach and White
(e) Cairns
(liquid)
(liquid)
(liquid). 


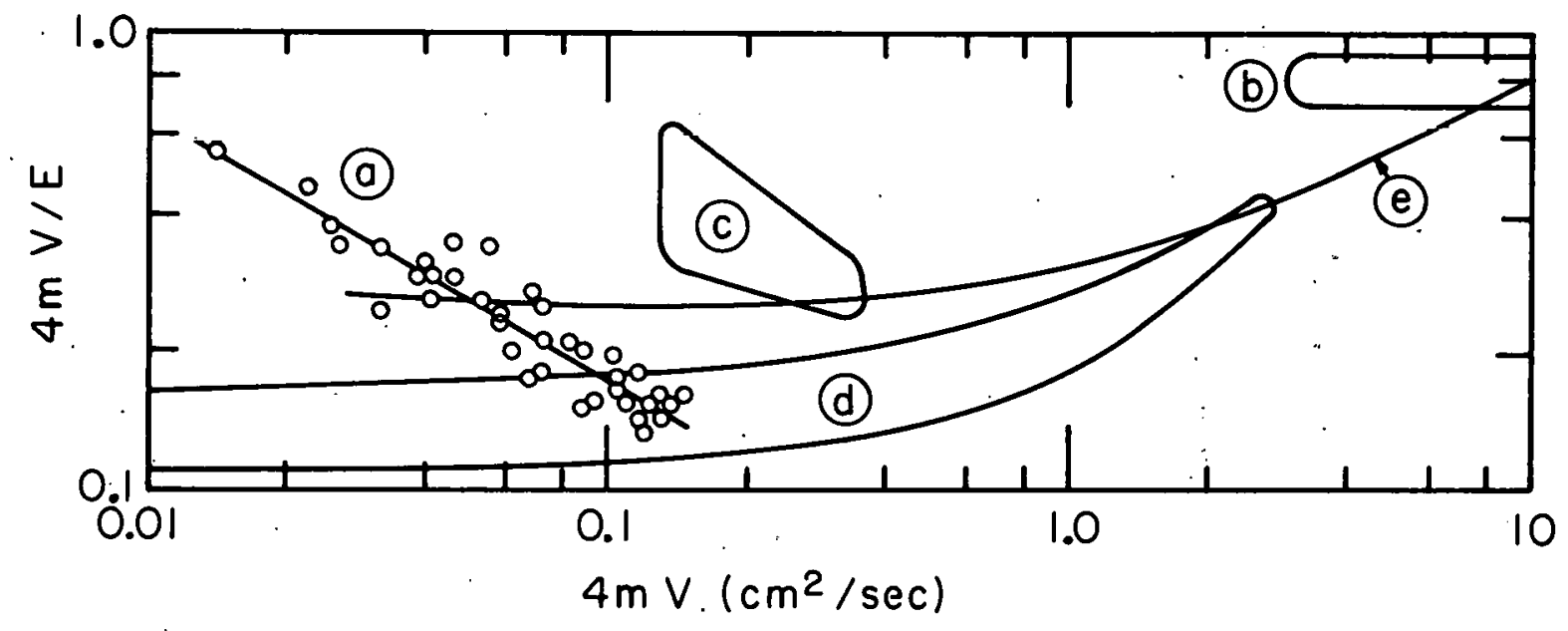

$M U-20182$

Fig. 13. Comparison with other data given as $4 \mathrm{~m} \mathrm{~V} / \mathrm{E}$ vs $4 \mathrm{~m} \mathrm{~V}$ (after Cairns).
(a) This work
(b) McHenry and Wilhelm
(c) Strang and Geankoplis
(gas)
(d) Carberry and Bretton, and Ebach and White
(e) Cairns
(liquid)
(Iiquid)
(liquid). 


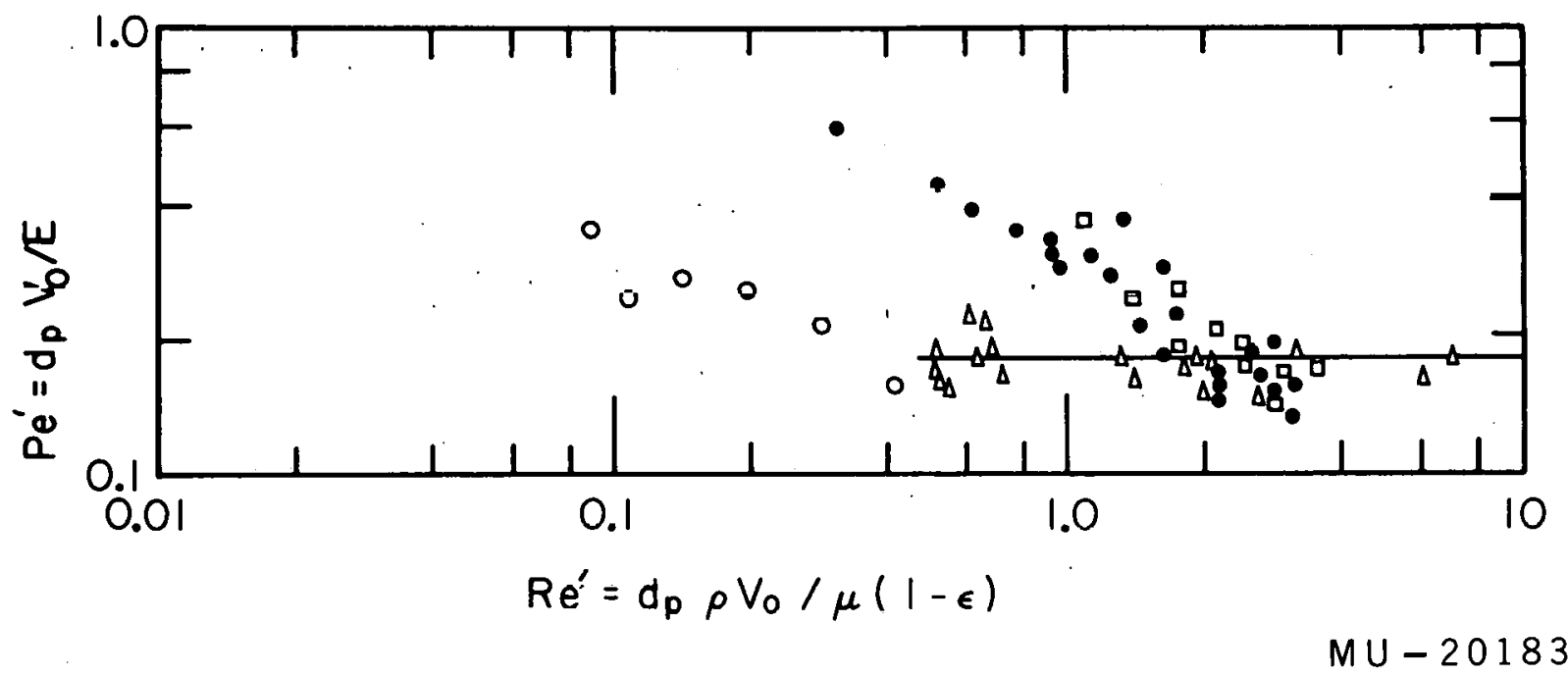

Fig. 14. Comparıson with the data of Jacyues, Cutter, and Vermeulen.

Key: $O$ helium-air system

- air-ethylene system

$\square$ nitrogen-ethylene system

$\Delta$ and - Jacques, Cotter, and Vermeulen. 


\section{Solution of Differential Equation}

The differential equation to be solved is

$$
D \frac{\partial^{2} c}{\partial x^{2}}-v \frac{\partial C}{\partial x}=\frac{\partial C}{\partial t},
$$

with two of the boundary conditions being

$$
\begin{aligned}
& C(x, 0)=0 \text { for all } x, \\
& \lim _{x \rightarrow \infty} C(x, t)=0 \text { for all } t .
\end{aligned}
$$

For a Step-Function Input

The third boundary condition is

$$
c(0, t)=: \begin{aligned}
& 0, t \leq 0 \\
& c_{0}, t>0
\end{aligned}
$$

Upon assumption of a solution of the form

$$
C=\psi \exp \left(\frac{V x}{2 \cdot D}-\frac{V^{2} t}{4 D}\right)
$$

Bq. (A 1) can be reduced to

$$
D \frac{\partial^{2} \psi}{\partial x^{2}}=\frac{\partial \psi}{\partial t},
$$

with boundary conditions

$$
\begin{aligned}
& \psi(x, 0)=0 \text { for all } x \\
& \lim _{x \rightarrow \infty} \psi(x, t)=0 \text { for all } t \\
& \psi(0, t)=C_{0} \exp \left(\frac{V^{2} t}{4 D}\right) .
\end{aligned}
$$


This system of equations can be solved by using the Laplace transformation,

$$
\bar{\psi}(x)=\int_{0}^{\infty} e^{-p t} \psi(x, t) d t .
$$

Equation (A 2) becomes

$$
D \frac{d^{2} \bar{\psi}}{d x^{2}}=p \bar{\psi}-\psi(x, 0+)=p \bar{\psi}
$$

with boundary conditions

$$
\begin{aligned}
& \bar{\psi}(\infty)=0, \\
& \bar{\psi}=\mathrm{C}_{0}\left(\frac{\mathrm{I}}{\mathrm{p}-\mathrm{v}^{2} / 4 \mathrm{D}}\right) .
\end{aligned}
$$

The solution of (A 3) is

$$
\bar{\psi}=A \exp (-\sqrt{\mathrm{p} / \mathrm{D}} \mathrm{x})+\mathrm{B} \exp (\sqrt{\mathrm{p} / \mathrm{D}} \mathrm{x}) .
$$

Applying Eq. (A 4), we find

$$
\begin{aligned}
& B=0, \\
& \bar{\psi}=A \exp (-\sqrt{p / D} x) .
\end{aligned}
$$

Applying Eq. (A 5), we find

$$
A=C_{0}\left(\frac{1}{p-v^{2} / 4 \cdot D}\right) \text {. }
$$

Therefore

$$
\bar{\psi}=\mathrm{C}_{0}\left(\frac{1}{\mathrm{p}-\mathrm{v}^{2} / 4 \cdot \mathrm{D}}\right) \exp (-\sqrt{\mathrm{p} / \mathrm{D}} \mathrm{x}) .
$$

The inverse transform of Eq. (A 7) : is ${ }^{2}$ 
$-34-$

$$
\begin{aligned}
\psi= & \frac{C}{2} \cdot\left[\exp \left(\frac{v^{2} t+2 V x}{4 D}\right) \operatorname{erfc}\left(\frac{x}{2 \sqrt{D t}}+\frac{v}{2} \sqrt{t / D}\right)\right. \\
& \left.+\exp \left(\frac{V^{2} t-2 V x}{4 D}\right) \operatorname{erfc}\left(\frac{x}{2 \sqrt{D t}}-\frac{V}{2} \sqrt{t / D}\right)\right],
\end{aligned}
$$

which gives

$$
\begin{aligned}
\frac{C}{C_{0}}= & \frac{1}{3}\left[\exp \left(\frac{V^{2} t+2 V x}{4 D}\right) \operatorname{erfc}\left(\frac{x+V t}{2 \sqrt{D t}}\right)\right. \\
& \left.+\exp \left(\frac{v^{2} t+2 V x}{4 D}\right) \operatorname{erfc}\left(\frac{x-V t}{2 \sqrt{D t}}\right)\right] \\
& \exp \left[-\left(\frac{v^{2} t-V x}{4 D}\right)\right] .
\end{aligned}
$$

Let $x=L, s=V L / D$, and $\eta=D t / L^{2}$; then

$$
\frac{c}{C_{0}}=\frac{1}{2}\left[e^{s} \operatorname{erfc}\left(\frac{1+s \eta}{2 \sqrt{\eta}}\right)+\operatorname{erfc}\left(\frac{1-s \eta}{2 \sqrt{\eta}}\right)\right] \text {, }
$$

where $\operatorname{erfc} z=I-\operatorname{erf} \cdot z=1-2 / \sqrt{\pi} \int_{0}^{z} e^{-u^{2}} \cdot d u$.

For a Pulse-Function Input

The third boundary condition is

$$
A \in \int_{0}^{\infty}\left(V C-D \frac{\partial C}{\partial x}\right) d t=q .
$$

The solution follows the same procedure except that Eqs. (A 3), (A 4), and (A 5) become 


$$
\begin{aligned}
& D \frac{d^{2} \bar{\psi}}{d x^{2}}=p \bar{\psi}, \\
& \bar{\psi}(\infty)=0, \\
& \frac{V}{2} \bar{\psi}-D \frac{d \bar{\psi}}{d x}=\frac{g}{A \epsilon} .
\end{aligned}
$$

Equation (A 6) is the same, and using (A B) and (A 9), we find,

$$
\bar{\psi}=\frac{\mathrm{q}}{\mathrm{A} \epsilon}\left(\frac{1}{\mathrm{v} / 2+\sqrt{\mathrm{pD}}}\right) \exp (-\sqrt{\mathrm{p} / D} \mathrm{x}) .
$$

The inverse transform of (A 10) is ${ }^{2}$

which gives

$$
\begin{gathered}
\psi=\frac{q}{A \epsilon}\left[\frac{1}{\sqrt{\pi D t}} \exp \left(-\frac{x^{2}}{4 D t}\right)-v / 2 D \exp \left(\frac{v^{2} t+2 v x}{4 D}\right)\right. \\
\left.\quad \operatorname{erfc}\left(\frac{x+V t}{2 \sqrt{D t}}\right)\right],
\end{gathered}
$$

$$
\begin{array}{r}
C=\frac{q}{A \epsilon}\left[\frac{1}{\sqrt{\pi D t}} \exp \left(-\frac{x^{2}}{4 D t}\right)-V / 2 D \exp \left(\frac{V^{2} t+2 V x}{4 D}\right)\right. \\
\left.\quad \operatorname{erfc}\left(\frac{x+V t}{2 \sqrt{D t}}\right)\right] \quad \exp \left(\frac{2 V x-V^{2} t}{4 D}\right),
\end{array}
$$

or

$$
C=\frac{q}{A L E}\left[\frac{1}{\sqrt{\pi \eta}} \exp \left[-\frac{(1-s \eta)^{2}}{4 \eta}\right]-s / 2 \operatorname{senfc}\left(\frac{1+s \eta}{2 \sqrt{\eta}}\right)\right]
$$




\section{Properties of Gases}

Helium

U. S. Navy, grade AA

purity

$99.99 \%$ :

molecular weight

density at $297^{\circ} \mathrm{K}, 24.7 \mathrm{psia}$

4.00

viscosity at $297^{\circ} \mathrm{K}$

$0.01721 \mathrm{lb} / \mathrm{ft}^{3}$

$0.0448 \mathrm{lb} / \mathrm{ft}-\mathrm{hr}$

Ethylene

Matheson, C.P. grade

purity

$99.5 \%$

molecular weight

density at $297^{\circ} \mathrm{K}, 24.7 \mathrm{psia}$

28.0

viscosity at $297^{\circ} \mathrm{K}, 24.7 \mathrm{psia}$

$0.1224 \mathrm{lb} / \mathrm{ft}^{3}$

$0.0244 \mathrm{lb} / \mathrm{ft}-\mathrm{hr}$

\section{Nitrogen}

National Cylinder and Gas, prepurified purity

molecular weight

dnesity at $297^{\circ} \mathrm{K}, 24.7 \mathrm{peia}$

$99.99 \%$

viscosity at $297^{\circ} \mathrm{K}$

28.0

$0.1224 \mathrm{lb} / \mathrm{ft}^{3}$

$0.0426 \mathrm{Ib} / \mathrm{ft}-\mathrm{hr}$

Air

Liquid Carbonic

molecular weight

density at $297^{\circ} \mathrm{K}, 24.7$ psia

29.0

viscosity at $297^{\circ} \mathrm{K}$

$0.1247 \mathrm{lb} / \mathrm{ft}^{3}$

$0.0433 \mathrm{Ib} / \mathrm{ft}-\mathrm{hr}$ 


$$
-37-
$$

\section{APPENDIX III}

\section{Calibration of Thermal-Conductivity Cell}

In order to convert the response of the thermal conductivity cell from voltage to concentration, calibration runs were made under conditionsisimilar to the operating conditions of the column. The voltage output of the $\mathrm{TC}$ cell, resulting from comparison of a mixture of known composition with the reference gas, was measured. The calibration curves are shown in Figs. 15, 16, and 17 . 


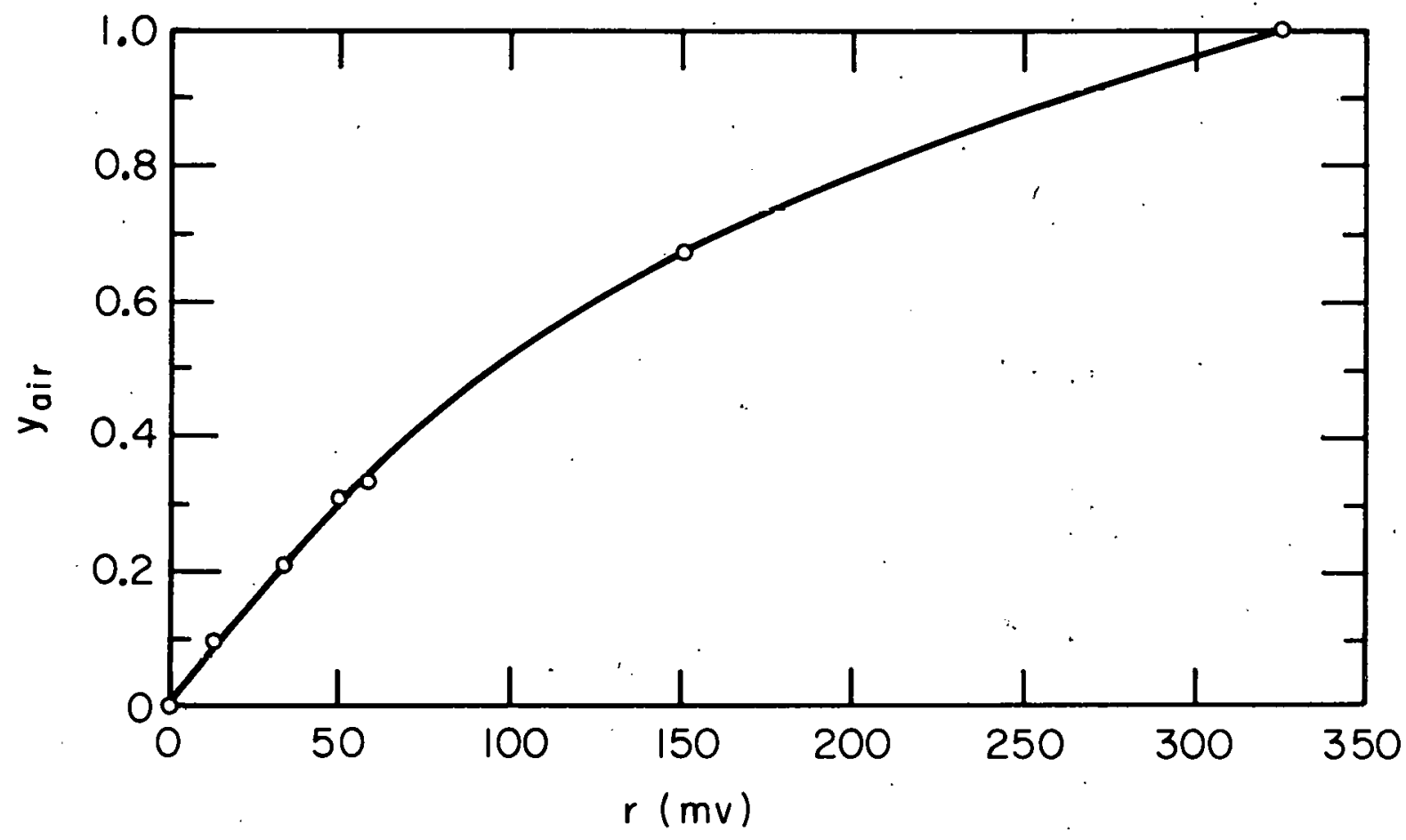

$M U-20184$

Fig. 15. Mole fraction air in helium-air mixture versus response of thermal-conductivity cell. 


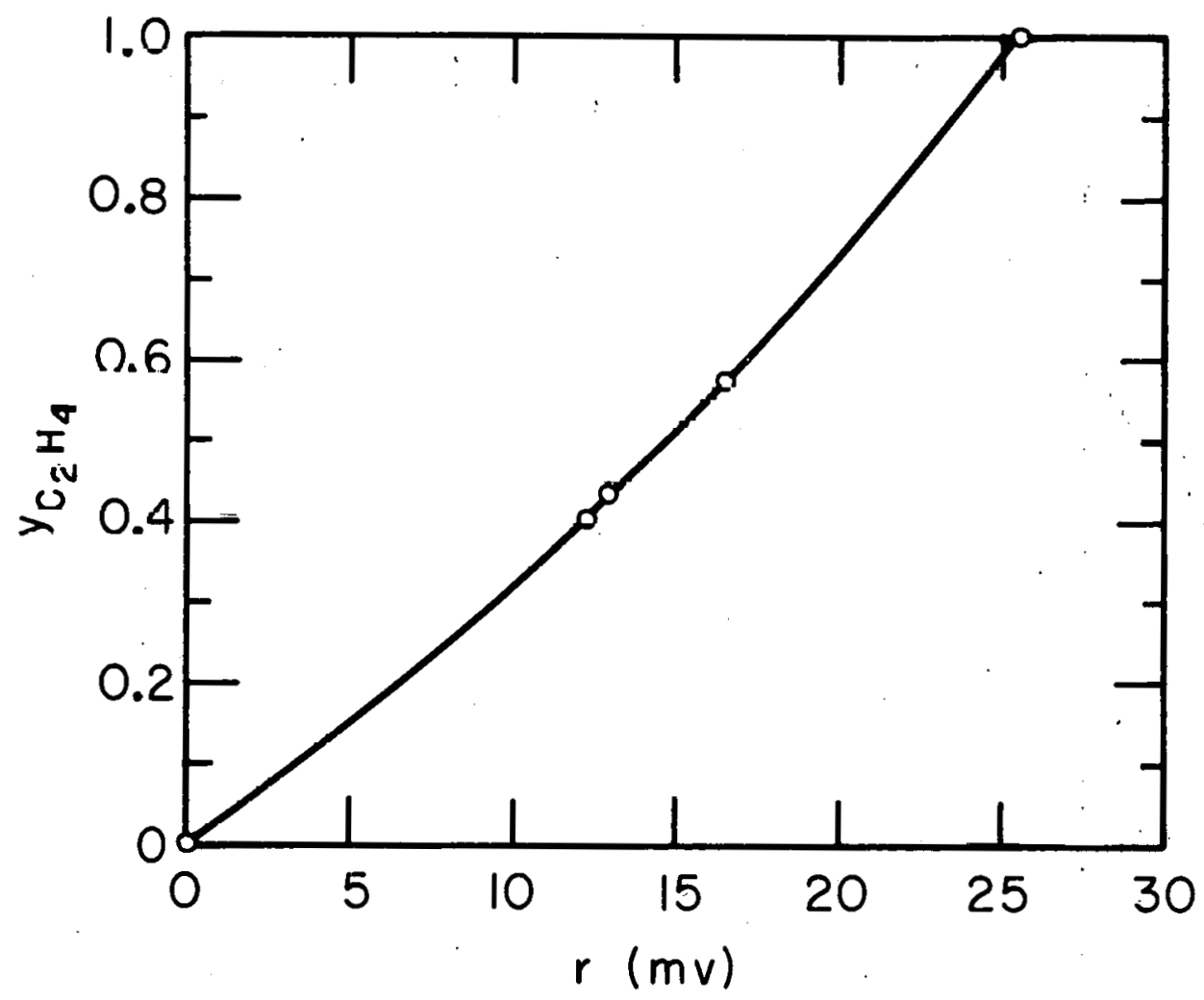

$M U-20185$

Fig. 16. Mole fraction ethylene in ethylene-air mixture versus response of thermal conductivity cell. 


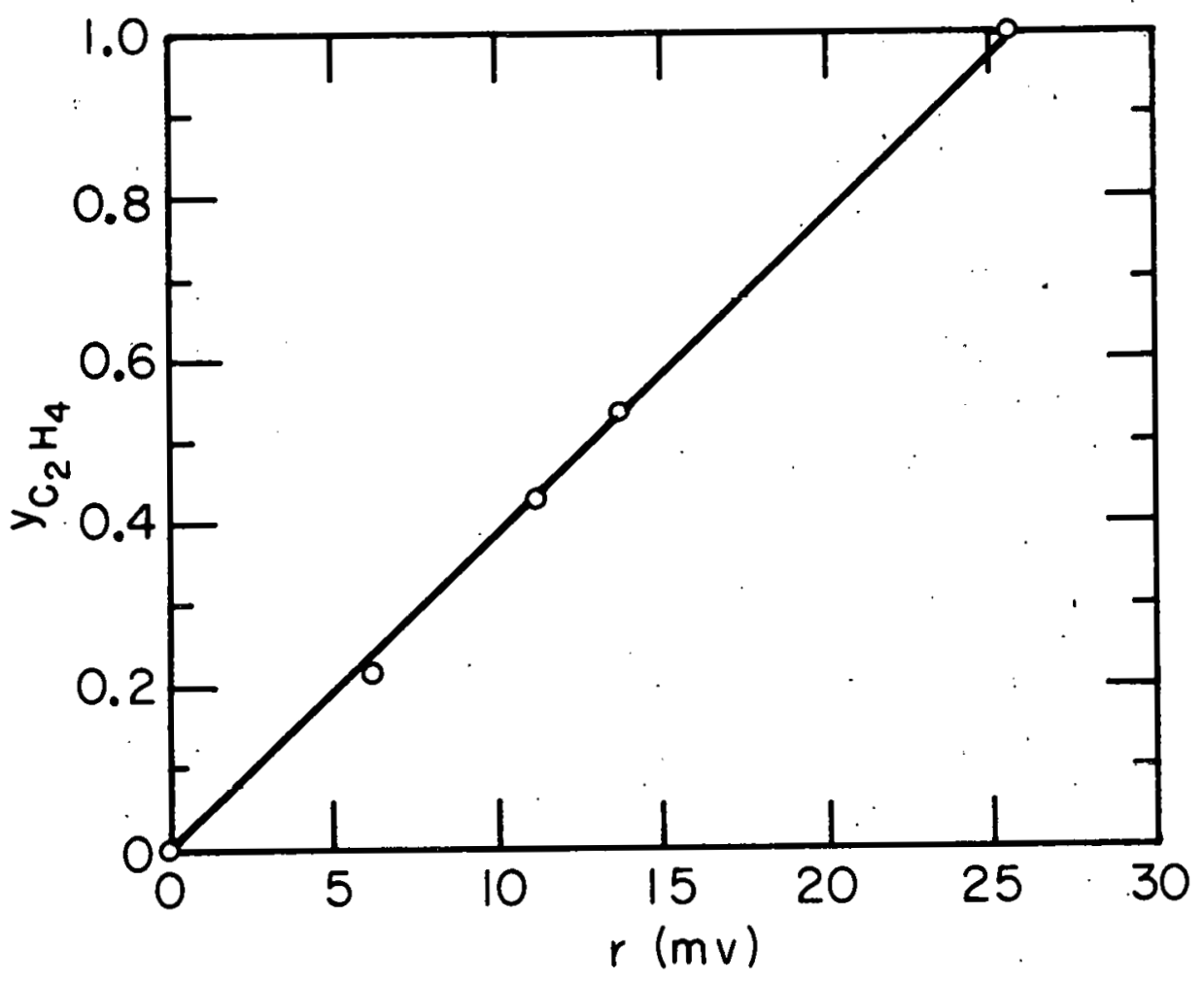

$$
M U-2.0186
$$

Fig. 17. Mole fraction ethylene in ethylene-nitrogen mixture versus response of thermal conductivity cell. 


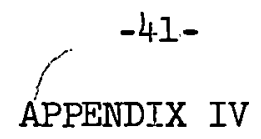

Sample Calculation for Run No. 106

\section{Constants}

Column area, A

Column pressure, P.

Length, $\mathrm{L}_{c}$, of connector from column exit to $\mathrm{TC}$ cell

Connector area, $\mathrm{A}_{\mathrm{c}}$

Void fraction of packing, $\epsilon$

Particie Qlameter, $a_{p}$

Gas density, $\rho$

Gas visrnsit.y, $\mu$

Column length, $\mathrm{L}$
$5.28 \times 10^{-4} \mathrm{ft}^{2}$

24.7 psia

$0.60 \mathrm{ft}$

$1.97 \times 10^{-4} \mathrm{ft}^{2}$

0.359

$2.05 \times 1 n^{-3} \mathrm{ft}$

$1.014 \times 10^{-3} \mathrm{P} 1 b / \mathrm{t}^{3} \mathrm{t}^{3}$

4.64... $10^{-2} \mathrm{lb} / \mathrm{t}^{\mathrm{t} t-\mathrm{hr}}$

$20 \mathrm{ft}$

$26.2 \mathrm{ml} / \mathrm{min}$

$7.14 \mathrm{~min}$

$31.5 \mathrm{mv} / \mathrm{min}$

$19.35 \mathrm{mv}$

\section{Calculations}

Correction for flow time through column-TC cell connector:

$t_{f}=L_{c} / v\left(A_{c}\right)(P / 14.7)$ (unit conversion factors),

$t_{f}=0.60 / 26.2\left(1.97 \times 10^{-4}\right)(24.7 / 14.7)(1000)(28.3)=0.21 \mathrm{~min}$,

$t_{.5}=t_{\text {mid }}-t_{f}=7.14-0.21=6.93 \mathrm{~min}$.

Gas-flow velocity:

$v_{0}=v / A(14.7 / P)$ (unit conversion factors)

* Gas properties for use in calculation of the Reynolds number were evaluated at $\mathrm{C} / \mathrm{C}_{0}=0.5$. 


$$
\begin{aligned}
& \mathrm{V}_{0}=26.2 / 5.28 \times 10^{-4}(14.7 / 24.7)\left[\frac{60}{1000(28.3)}\right]=62.7 \mathrm{ft} / \mathrm{hr}, \\
& \mathrm{V}=\mathrm{V}_{0} / \epsilon=62.7 / 0.359=174.6 \mathrm{ft} / \mathrm{hr} .
\end{aligned}
$$

Reynolds number:

$\operatorname{Re}=\alpha_{p} \rho V_{o} / \mu=\frac{2.05 \times 10^{-3}\left(1.014 \times 10^{-3}\right)(24.7)(62.7)}{4.64 \times 10^{-2}}=0.0695$

4 m V:

$4 m \mathrm{~m}=\frac{\mathrm{D}_{c} \epsilon \mathrm{V}}{3 / 2 \mathrm{D}_{\mathrm{c}} / \mathrm{d}_{\mathrm{p}}(1-\epsilon)+1}=\frac{0.311(0.359)(174.6)}{3 / 2(0.311 / 0.0246)(1-0.359)+1}$

$4 \mathrm{mV}=0.1237 \mathrm{ft}^{2} / \mathrm{hr}$,

$4 \mathrm{~m} \mathrm{~V}=0.0320 \mathrm{~cm}^{2} / \mathrm{sec}$.

s:

$s=4 \pi\left(t_{.5} / y_{0} \quad \therefore \mathrm{dy} / \mathrm{dt}\right)^{2} t_{t=t^{\prime}} \cdots$

Since we have $\mathrm{y}_{0} \cong 0.14, \mathrm{Fig} .14$ shows that the $\mathrm{y}$-versus $-\mathrm{r}$ calibration curve is approximately a straight line over the region of interest. Therefore,

$$
\begin{aligned}
& \mathrm{y} / \mathrm{y}_{\mathrm{o}}=\mathrm{r} / \mathrm{r}_{\mathrm{o}} ; \\
& 1 / \mathrm{y}_{\mathrm{o}} \mathrm{dy} / \mathrm{dt}=1 / \mathrm{r}_{\mathrm{o}} \mathrm{dr} / \mathrm{dt},
\end{aligned}
$$

and

$$
\begin{aligned}
& s=4 \pi\left(t_{.5} / r_{0} d r / d t\right)^{2} t_{=} t_{.5}, \\
& s=4 \pi[6.93 / 19.35 \quad(31.5)]^{2}=1601 .
\end{aligned}
$$

Peclet number:

$P e=s \cdot d_{p} / L=1601\left(2.0 \times 10^{-3} / 20\right)=0.1641$.

Eddy-dispersion coefficient

$$
\begin{aligned}
& \mathrm{E}=\mathrm{V} \mathrm{L} / \mathrm{s}-\mathrm{D}_{\mathrm{m}}=174.6(20)(.258) / 160 \mathrm{I}-0.425, \\
& \mathbf{E}=0.137 \mathrm{~cm}^{2} / \mathrm{sec} .
\end{aligned}
$$


$-43-$

$\frac{4 \mathrm{mV}}{\mathrm{E}}:$

$$
\frac{4 \mathrm{mV}}{\mathrm{E}}=\frac{0.0320}{0.137}=0.234
$$


$-44-$

APPENDIX V

Table I. Experimental Data

$$
\begin{aligned}
& \mathrm{T}=297^{\circ} \mathrm{K} \\
& \mathrm{p}=24.7 \text { psia }
\end{aligned}
$$

pressure drop $\cong 0.0014 \mathrm{v} \frac{\text { psia }}{\text { ft: of column }}$

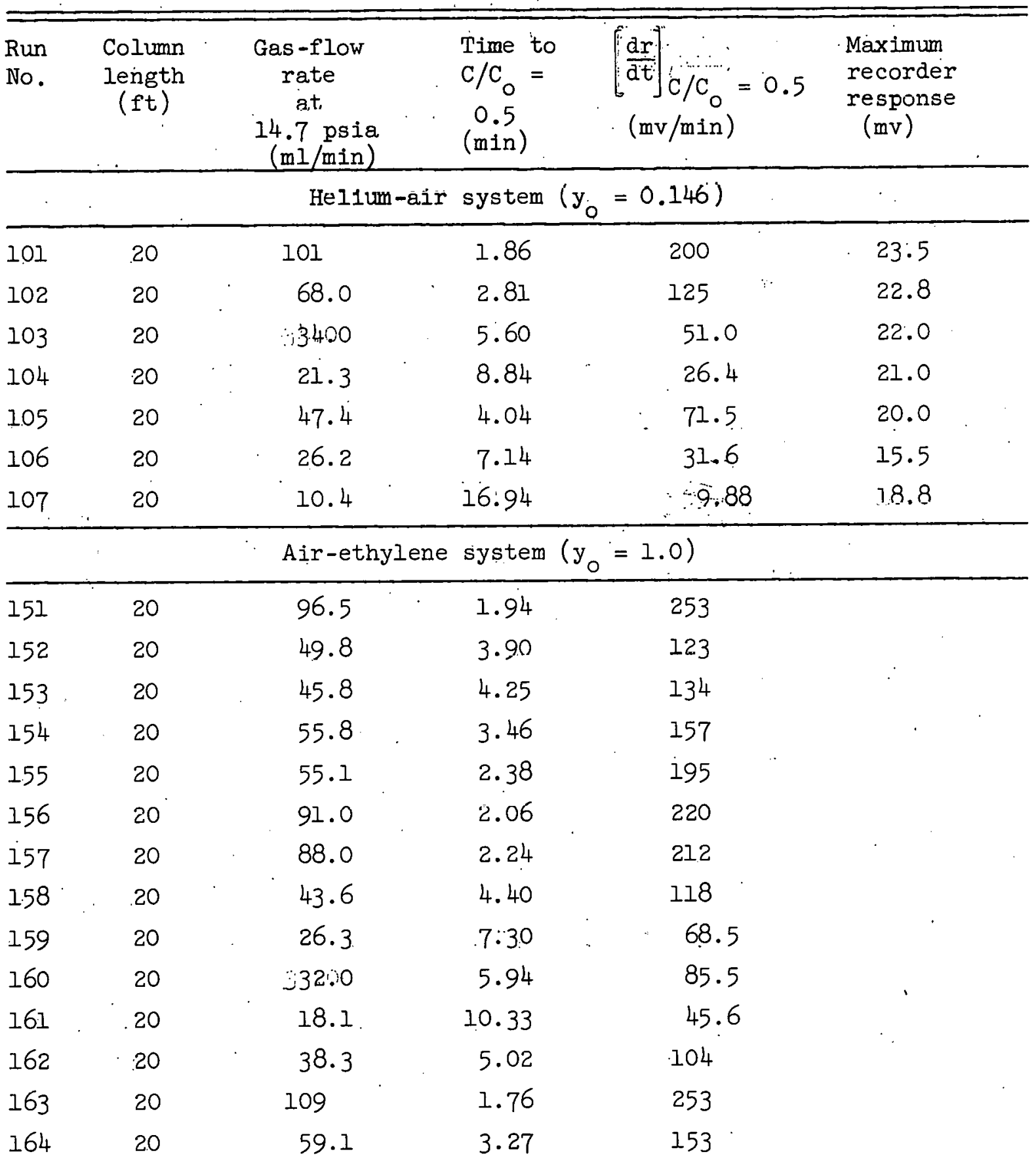


Table I (continued)

\begin{tabular}{|c|c|c|c|c|c|}
\hline $\begin{array}{l}\text { Run } \\
\text { No. }\end{array}$ & $\begin{array}{r}\text { Column } \\
\text { length } \\
(\mathrm{ft}) \\
\therefore\end{array}$ & $\begin{array}{c}\text { Gas }-f l o w \\
\text { rate } \\
\text { at } \\
14.7 \text { psia } \\
(\mathrm{ml} / \mathrm{min})\end{array}$ & $\begin{array}{l}\text { Time to } \\
\mathrm{C} / \mathrm{C}_{0}= \\
0.5 \\
(\min )\end{array}$ & $\begin{array}{l}{\left[\frac{d r}{d t}\right]_{C / C_{0}}=0.5} \\
(m v /\lfloor\perp s)\end{array}$ & $\begin{array}{l}\text { Maximum } \\
\text { recorder } \\
\text { response } \\
\quad(\mathrm{mv})\end{array}$ \\
\hline 165 & . 20 & . $\quad 32.8$ & 5.78 & 89.0 & \\
\hline 166 & 20 & 20.1 & 9.29 & 52.2 & \\
\hline 167 & 20 & 11.4 & 15.77 & 26.2 & \\
\hline .1 .68 & 20 & 75.0 & 2.57 & 166 & \\
\hline 169 & '¿'U & 7560 & 3.57 : & 1.75 & . \\
\hline 201 & 40 & 98.0 & 3.63 & 170 & . \\
\hline 202 & 40 & $106^{\circ}$ & 3.40 & 182 & \\
\hline 203 & 40 & 72.5 & 5.06 & 123 & \\
\hline 204 & 40 & 32.0 & 11.76 & 60.0 & \\
\hline \multicolumn{6}{|c|}{ Nitrogen-ethylene system $\left(\mathrm{y}_{\mathrm{o}}=1.0\right)$} \\
\hline 251 & 40 & 98.3 & 3.48 & 186 & 27.2 \\
\hline 252 & 40 & 83.4 & 4.28 & 170 & 26.5 \\
\hline 3'ל'ל & 40 & 72.9 & 1.95 & 143 & 25.8 \\
\hline 254 & 40 & 58.8 & 6.15 & 108 & 25.5 \\
\hline 255 & 40 & 47.0 & $7 \cdot 79$ & 90.0 & 25.2 \\
\hline 256 & 40 & 121 & .2 .93 & 233 & 26.2 \\
\hline 257 & 40 & 104 & 3.48 & 186 & 25.5 \\
\hline 258 & 40 & 86.3 & 4.24 & 152 & 25.0 \\
\hline 259 & 40 & 59.1 & 6.28 & 114 & 24.5 \\
\hline 260 & 40 & 37.8 & 9.99 & 75.0 & 24.5 \\
\hline
\end{tabular}




\section{$-16-$}

Table II: Calculated results

\begin{tabular}{|c|c|c|c|c|c|c|c|}
\hline $\begin{array}{l}\text { Run } \\
\text { No. }\end{array}$ & $\begin{array}{c}t \\
(\min ) \\
\end{array}$ & $s$ & $\mathrm{Pe}$ & $\operatorname{Re}$ & $\left(\mathrm{cm}^{2} / \mathrm{sec}\right)$ & $\begin{array}{c}4 \mathrm{mV} \\
\left(\mathrm{cm}^{2} / \mathrm{sec}\right) \\
\end{array}$ & $4 \mathrm{mV} / \mathrm{E}$ \\
\hline 1.01 & 1.80 & 2820 & 0.289 & 0.268 & 0.805 & 0.1232 & 0.153 \\
\hline 102 & 2.73 & 2830 & 0.290 & 0.1803 & 0400 & 0.0830 & 0.207 \\
\hline 103 & 5.44 & 2000 & 0.205 & 0.0901 & 0.159 & 0.0415 & 0.261 \\
\hline 104 & 8.58 & 1459 & 0.1496 & 0.0565 & 0.076 & 0.0260 & 0.342 \\
\hline 105 & 3.92 & 2460 & 0.252 & $0: 1257$ & 0.237. & 0.0578 & 0.244 \\
\hline 106 & 6.93 & 1601 & 0.1641 & 0.0595 & 0.137 & 0.0320 & 0.234 \\
\hline 107 & 16.40 & 938 & 0.0961 & 0.0276 & $-\cdots$ & 0.01 .27 & -- \\
\hline 151 & 1.88 & 4450 & 0.456 & 1.803 & 0.645 & 0.1178 & 0.182 \\
\hline 152 & 3.79 & 4250 & 0.437 & 0.930 & 0.301 & 0.0608 & 0.202 \\
\hline 153 & 4.13 & 6040 & 0.619 & 0.855 & $0.161^{\circ}$ & 0.0559 & 0.347 \\
\hline 154 & $3 \cdot 36$ & 5440 & 0.558 & 1.041 & 0.252 & 0.0680 & 0.270 \\
\hline $155^{\circ}$ & 2.28 & 3880 & 0.398 & 1.027 & 0.387 & 0.0672 & 0.174 \\
\hline 156 & 2.00 & 3800 & 0.390 & 1.697 & 0.721 & 0.1110 & 0.154 \\
\hline 157 & 2.18 & 4200 & 0.431 & 1.643 & 0.619 & 0.1073 & 0.174 \\
\hline 158 & .4 .27 & 4950 & 0.507 & 0.815 & 0.202 & 0.0532 & 0.264 \\
\hline 159 & 7.09 & 4530 & 0.475 & 0.497 & 0.095 & 0.0321 & 0.339 \\
\hline 160 & 5.76 & 4750 & 0.488 & 0.598 & 0.131 & 0.0391 & 0.298 \\
\hline $161:$ & 10.02 & 4100 & 0.421 & 0.338 & 0.051 & 0.0221 & 0.432 \\
\hline 162 & 4.87 & 5080 & 0.521 & 0.71 .5 & 0.159 & 0.0468 & 0.294 \\
\hline 163 & 1.71 & 3680 & 0.378 & 2.04 & 0.91 .5 & 0.1330 & 0.145 \\
\hline 164 & 3.17 & 4630 & 0.475 & 1.105 & 0.338 & 0.0722 & 0.214 \\
\hline 165 & 5.61 & 4900 & 0.501 & 0.612 & 0.130 & 0.0400 & 0.308 \\
\hline 166 & 9.01 & 4350 & 0.446 & 0.394 & 0.0665 & 0.0258 & 0.388 \\
\hline 167 & 15.28 & 3140 & 0.322 & 0.213 & 0.0246 & 0.0139 & 0.565 \\
\hline 168 & 2.50 & 3380 & 0.347 & 1.400 & 0.660 & 0.0915 & 0.139 \\
\hline 169 & 2.50 & 3800 & 0.389. & 1.400 & 0.579 & 0.0915 & 0.158 \\
\hline 201 & 3.57 & 7230 & 0.370 & 1.830 & 0.832 & 0.1195 & 0.144 \\
\hline 202 & $3 \cdot 35$ & 7340 & 0.376 & 1.974 & 0.890 & 0.1290 & 0.145 \\
\hline 203 & 4.98 & 7350 & 0.376 & 1.353 & 0.579 & 0.0885 & 0.153 \\
\hline
\end{tabular}


$-47-$

Table II (continued)

\begin{tabular}{|c|c|c|c|c|c|c|c|}
\hline $\begin{array}{l}\text { Run } \\
\text { No. }\end{array}$ & $\begin{array}{r}t \\
(\min ) \\
\end{array}$ & $\mathbf{s}$ & $\mathrm{Pe}$ & $\operatorname{Re}$ & $\left(\mathrm{cm}^{2} / \mathrm{sec}\right)^{E}$ & $\left(\mathrm{~cm}^{2} / \mathrm{sec}\right)$ & $4 \mathrm{mV} / \mathrm{E}$ \\
\hline 204 & 11.58 & 9460 & 0.485 & 0.598 & .0 .132 & 0.0391 & 0.296 \\
\hline 251 & 3.42 & 6840 & $0.35,0$ & 1.813 & $0.89 i$ & 0.1194 & 0.134 \\
\hline 252 & 4.21 & 9150 & 0.469 & 1.540 & 0.530 & 0.1017 & 0.192 \\
\hline 253 & 4.87 & 9230 & 0.473 & 1.342 & 0.445 & 0.0889 & 0.200 \\
\hline 254 & 6.05 & 8160 & 0.418 & 1.084 & 0.398 & 0.0717 & 0.180 \\
\hline 255 & 7.67 & 9390 & 0.481 & 0.869 & 0.247 & 0.0573 & 0.232 \\
\hline 256 & 2.00 & 8.30 & 0.422 & 2.23 & 0.913 & 0.1477 & 0.162 \\
\hline .257 & 3.43 & $7850^{\circ}$ & 0.402 & 1.920 & 0.813 & 0.1269 & U.LלÉ \\
\hline 258 & 4.18 & 8070 & 0.413 & 1.589 & 0.638 & 0.103' & 0.165 \\
\hline .259 & 6.19 & 10460 & 0.535 & 1.091 & 0.292. & 0.0722 & 0.247 \\
\hline 260 & 9.84 & 11380 & 0.583 & 0.698 & 0.131 & 0.0462 & 0.353 \\
\hline
\end{tabular}


APPENDIX VI

Numerical Comparison of Solutions of Differential Equation

Equation (1) has been solved by several investigators for a pulse-function input. Some of the solutións, in the nomenclature of this work, are as follows.

This work:

$$
C=\frac{q}{A L \epsilon}\left[\frac{1}{\sqrt{\pi \eta}} \quad \exp \left[-\frac{(1-s \eta)^{2}}{4 \eta}\right]-\frac{s}{2} e^{s} \operatorname{erfc}\left(\frac{1+s \eta}{2 \sqrt{\eta}}\right)\right]
$$

Carberry and Bretton: 4

$$
C=\frac{q}{2 A L \in \sqrt{\pi \eta}} \exp \left[-\frac{(1-s \eta)^{2}}{4 \eta}\right]
$$

Ebach and white: 7 .

$$
C=\frac{q}{2 A I \in \sin \sqrt{\pi \eta}} \exp \left[-\frac{(1-s \eta)^{2}}{4 \eta}\right]
$$

R. H. Houston: 9

$$
\begin{aligned}
C= & \frac{q}{4 A I \epsilon}\left[\frac{4}{\sqrt{\pi \eta}}\left(\frac{s^{2} \eta}{4}+\frac{1}{2}\right) \exp \left[-\frac{(1-s \eta)^{2}}{4 \eta}\right]\right. \\
& \left.-2\left(\frac{s^{3} \eta}{4}+s+\frac{s^{2}}{4}\right) e^{s} \operatorname{erfc}\left(\frac{1+s \eta}{2 \sqrt{\eta}}\right)\right] .
\end{aligned}
$$

Equations (A II) through …... (A 14) were numerically evaluated

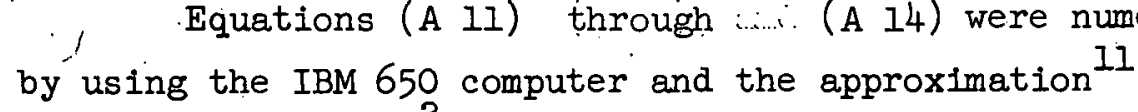

$$
\operatorname{erfc} x=\frac{e^{-x^{2}}}{x \sqrt{\pi}}\left(1-\frac{1}{2 x^{2}}+\frac{1 \cdot 3}{4 x^{4}}-\frac{1 \cdot 3 \cdot 5}{8 x^{6}}+\cdots\right) \text {. }
$$

Figures 18, 19, and 20 show concentration as a function of the dimensionless time variable, $s \eta$, with $s$ as a parameter. The constants used in the evaluation of Eqs (A 1 ( ) (through $q=7.60 \times 10^{-7} \mathrm{lb}$ mole, $A=5.15 \times 10^{-4} \mathrm{ft}^{2}, L=6.90 \mathrm{ft}, \epsilon=0.410$. It is apparent from these graphs that as $s$ increases, the difference between the various solutions decreases, and the curves approach a Gaussian distribution with $\mathrm{C}_{\max }$ at $\mathrm{s} \eta=1$. 


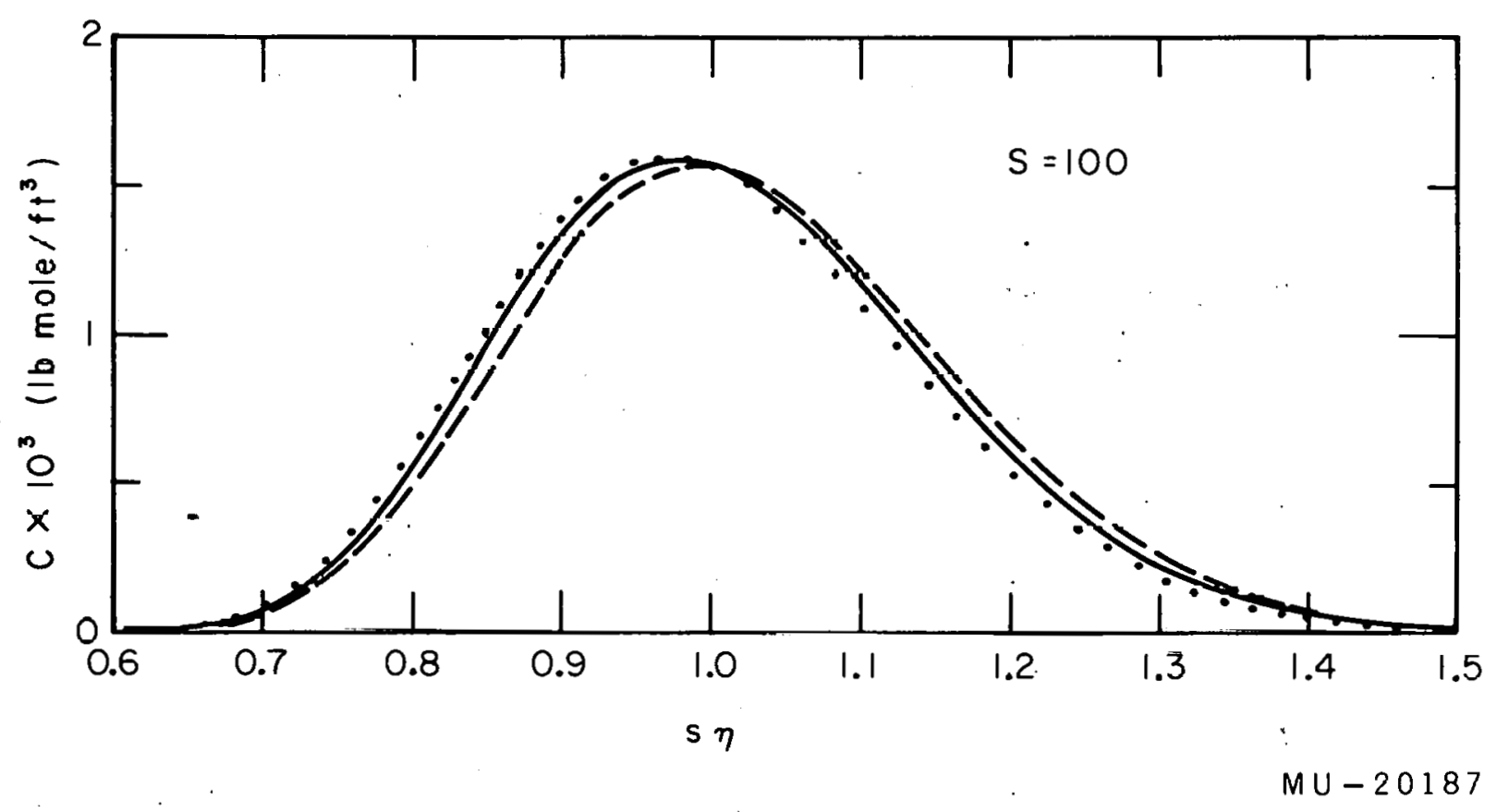

Fig. 18. Concentration at $x=I$ versue dimensionless time for $s=100$.

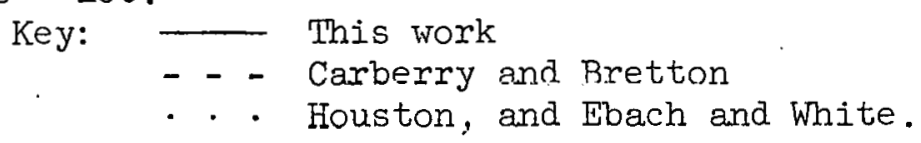

- Houston, and Ebach and White. 


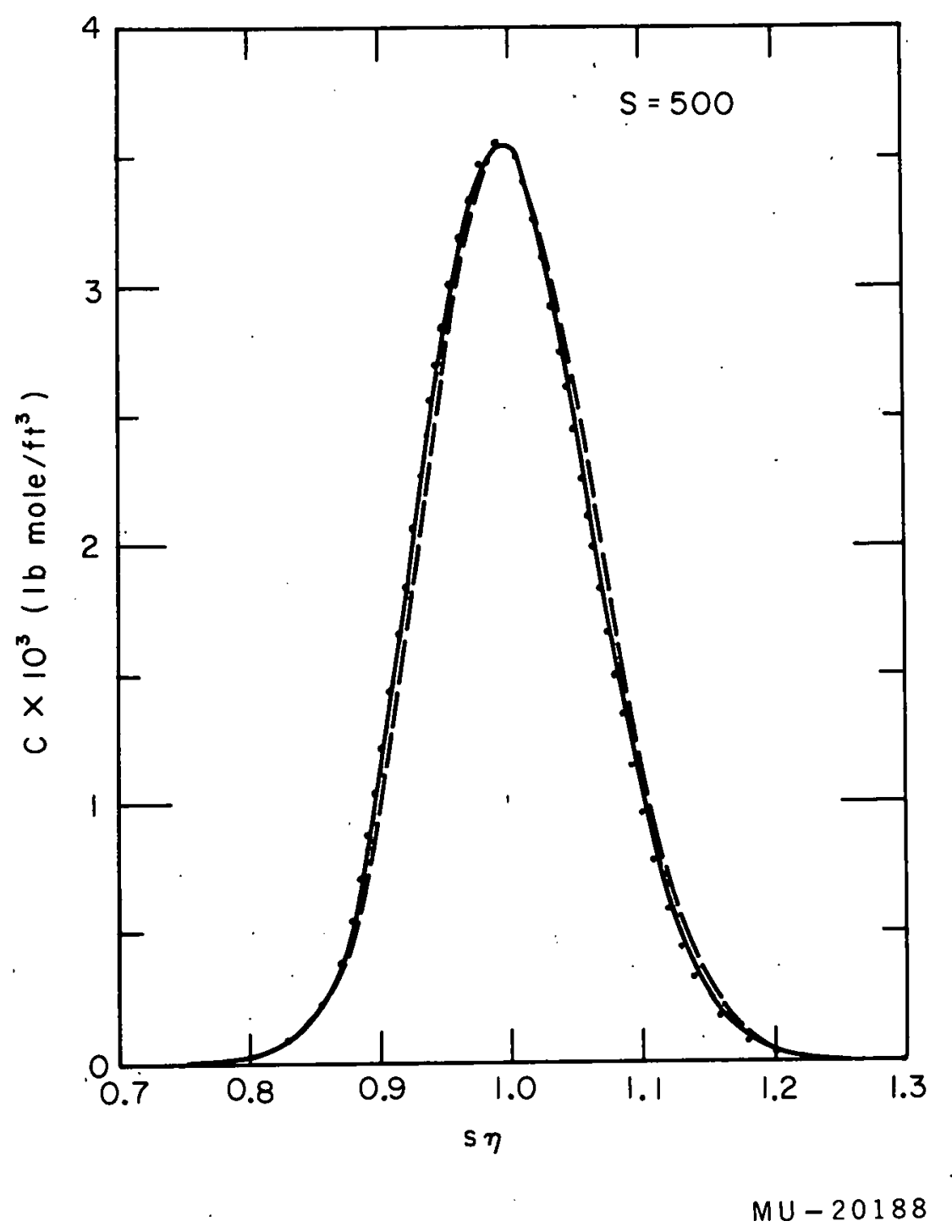

Fig. 19. Concentration at $x=I$ versus dimensionless time for $s=500$.

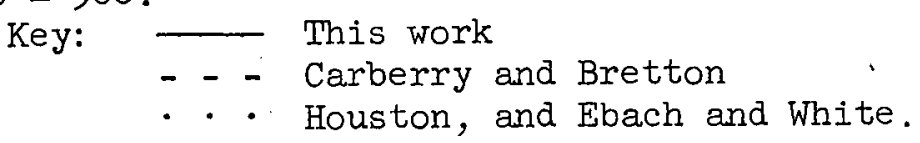




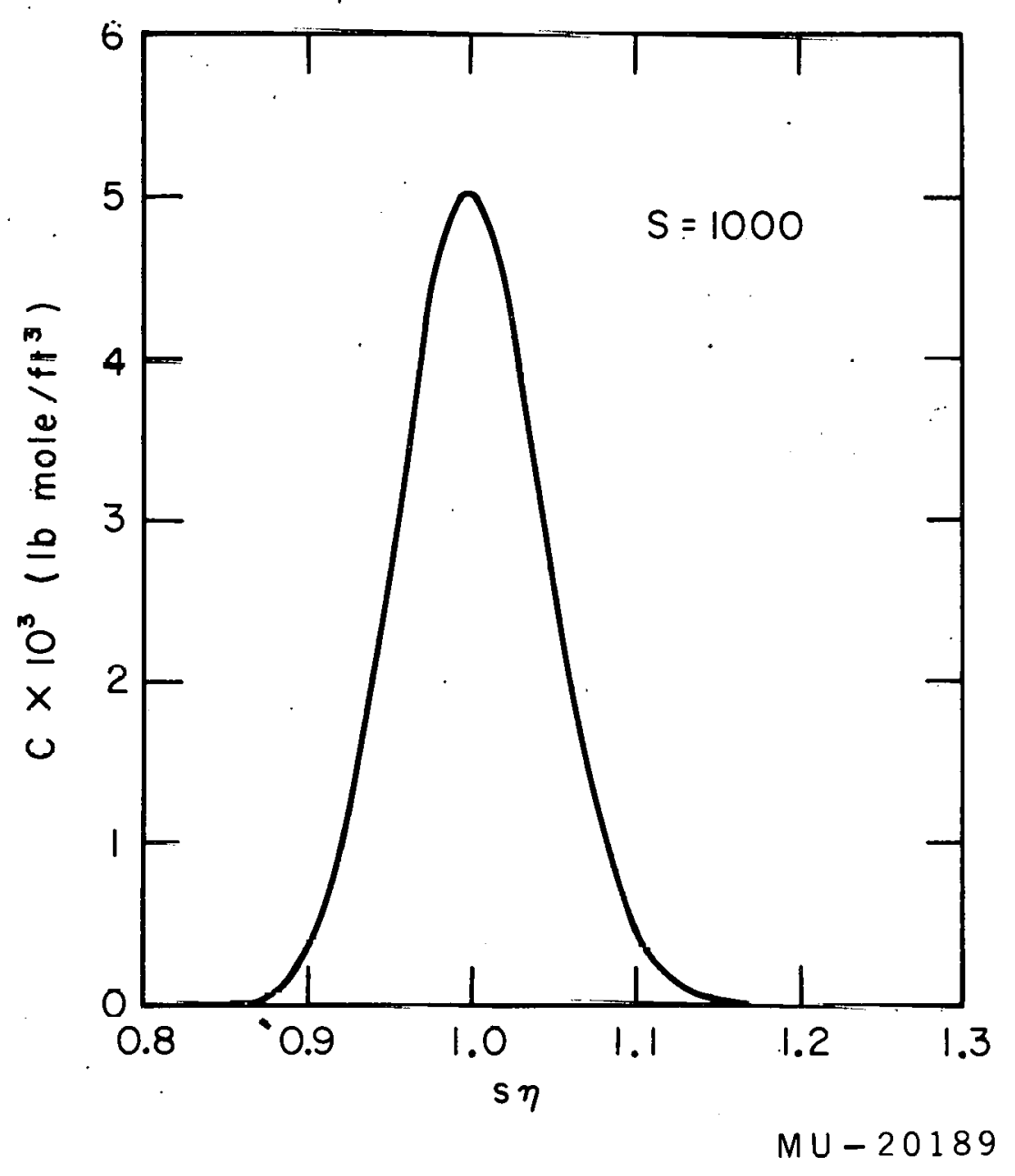

Fig. 20. Concentration at $\mathrm{x}=\mathrm{L}$ versus dimensionless time for $\mathrm{s}=1000$. Key: - This work; Carberry and Bretton; Houston; and Ebach and White. 


\section{NOMENCLATURE}

A

$\mathrm{A}_{\mathrm{C}}$

C

C

D

$\mathrm{D}_{\mathrm{c}}$

$\mathrm{D}_{\mathrm{m}}$

$\mathrm{d}_{\mathrm{p}}$

E

I

$\mathrm{L}_{\mathrm{c}}$

$\mathrm{N}_{\mathrm{e}}$

$\mathrm{P}$

$\mathrm{Pe}$

$\mathrm{Pe}$ :

q

R

$\mathrm{Re}$

$\mathrm{Re}^{\prime}$

r

ro

s

$\mathrm{T}$

t

$t_{f}$

$t_{\operatorname{mid}}$

$t .5$ cross-sectional area of empty column.

column-TC cell connector area

concentration of solute gas

concentration of input step-function gas

longitudinal dispersion coefficient

inside diameter of column

molecular diffusion coefficient

particle diameter

eddy-dispersion coefficient

column length

column-TC cell connector length

mass flux due to eddy dispersion

column pressure

Peclet number, $d_{p} v / D$

modified Peclet number, $\mathrm{d}_{\mathrm{p}} \mathrm{v}_{\mathrm{o}} / \mathrm{D}$.

quantity of gas charged in a pulse input

gas constant

Reynolds number, $d_{p} p V / \mu$

modified Reynolds number, $\operatorname{Re} / 1-\epsilon$

recorder response

recorder response due to input step-function gas

dimensionless mixing parameter, VL/D

temperature

time

flow time through column-TC cell connector

time at which $\mathrm{C} / \mathrm{C}_{0}=0.5$ (uncorrected for $t_{f}$ )

time at which $c / c_{o}=0.5, t_{\text {mid }}-t_{f}$ 
$\rho$

$\mu$

volumetric flow rate of gas at 1 atmosphere, $\mathrm{ml} / \mathrm{min}$ superficial velocity

interstitial velocity, $\mathrm{v}_{\mathrm{o}} / \epsilon$

axial distance from column entrance

mole fraction of solute gas

mole fraction of input step-function gas

dimensionless parameter, $\mathrm{Dt} / \mathrm{L}^{2}$

density

viscosity 


\section{BIBLIOIRAPHY}

1. R. Aris and N. R. Amundson, A. I. Ch. E. Journal 3, 280 (1957).

2. Harry Bateman, Tables of Integral Transforms, Vol. I. (McGraw Hill Book Company; Inc., New York, 1954).

3. I. A. Bromley and C. R. Wilke, Ind. Eng. Chem. 43, 1641 (1951).

4. J. J. Carberry and R. H. Bretton, A. I. Ch. E. Journal 4, 367 $(1958)$.

5. E. J. Cairns, Mixing Properties and Chemical Kinetics in Chemical Flow Reactors (Dissertation), University of California, 1959.

6. P. V. Danckwerts, Chem. Eng. Sci. $\underline{2}$, I (1953).

7. E. A. Ebach and R. R. White, A. I. Ch. E. Journal 4, 161 (1958):

8. H. A. Finstein, Dissertation, Eidg. Techn. Hochschule, Zurich (1937).

9. R. H. Houston, A Theory for Industrial Gas-Liquid Ċhromatographic Columns (Thesis), University of Calffornia Radiation Laboratory Report UCRL-3817, April 1958.

10. G. I. Jacques, J. E. Cotter, and T. Vermeulen, Longitudinal Dispersion in Packed Extraction Columns, Lawrence. Radiation Laboratory Report UCRL-8658, April 1959.

11. E. Jahnke and F. Emde, Tables of Functions, fourth edition (Dover Publications, New York, 1945).

12. A. I. M. Keulemans, Gas Chromatography (Reinhold Publishing Corporation, New York, 1957). 
13. A. Klinkenberg and F. Sjenitzer, Chem. Eng. Sci., 5, 258 (1956).

14. K. W. McHenry and R. H. Wilhelm, A. I. Ch. E. Journal, 3, 83 (1957).

15. J. M. Prothisiliz, A. I. Ch. T. Journal 4, 14.M (1958).

16. R. C. Reid and T. K. Sherwood, The Properties of Gases and Liquids (McGraw.Hill Book Company, Inc., New York, 1958).

17. D. A. Strang and C. J. Geankoplis, Ind. Eng. Chem. 50, 1305 (1958). 
This report was prepared as an account of Government sponsored work. Neither the United States, nor the Commission, nor any person acting on behalf of the Commission:

A. Makes any warranty or representation, expressed or implied, with respect to the accuracy, completeness, or usefulness of the information, contained in this report, or that the use of any information, apparatus, method, or process disclosed in this report may not infringe privately owned rights; or

B. Assumes any liahilities with rcapcet to llie use of, or for damages resulting from the use of any information, apparatus, method, or process disclosed in this report.

As used in the above, "person acting on behalf of the Commission" includes any employee or contractor of the Commission, or employee of such contractor, to the extent that such employee or contractor of the Commission, or employee of such contractor prepares, disseminates, or provides access to, any information pursuant to his employment or contract.? with the Commission, or his employment with such contractor. 